\title{
Behaviour of a sensitive marine sediment: microstructural investigation
}

\author{
M. HATTAB*, T. HAMMAD $\dagger$, J.-M. FLEUREAU† and P.-Y. HICHER
}

\begin{abstract}
* Laboratoire d'Etude des Microstructures et de Mécanique des Matériaux, Universiié de Lorraine, Metz, France.
† Laboratoire de Mécanique des Sols, Structures et Matériaux, Ecole Centrale Paris, Châtenay Malabry, France.

\$ Institut de Recherche en Génie Civil et Mécanique, Ecole Centrale de Nantes, France.
\end{abstract}

The aim of this study is to characterise along various stress paths the microstructural evolution of a deep-water marine sediment from the Gulf of Guinea (GoG). Results obtained at the macroscopic level have shown that the phenomenological behaviour of the GoG sediment is explained by the properties of remoulded samples given by the isotropic and critical state lines, and by the properties of the intact samples given by the damage evolution of the inter-aggregate bonds. Microstructural investigations conducted by mercury intrusion porosimetry and scanning electron microscopy demon-strate that the volumetric strains measured at the macroscopic level come from inter-aggregate pore variations associated with the degrading of the inter-aggregate bonds. The mechanism responsible for reorienting the particles appears to apply in the case of the remoulded sediment. As for the natural sediment, it is first necessary to increase the isotropic consolidation stress towards higher values in order to break the bonds between the aggregates before it becomes possible to activate the particle reorientation mechanism and thus approach the remoulded behaviour.

KEYWORDS: anisotropy; clays; fabric/structure of soils; laboratory tests; microscopy

\section{INTRODUCTION}

This paper presents the results of an experimental study on the behaviour of a deep-water marine sediment from the Gulf of Guinea (GoG). The site is located on the continental shelf, in an oil-producing area where the concern is high to ensure the stability of deep structures (such as buried pipelines and suction anchors). The soil is a normally consolidated structured clay with a small amount of cohesion (De Gennaro et al., 2005; Hattab \& Favre, 2010) due to physical-chemical cementation, which has developed throughout the sedimentation and consolidation process in the seabed. Its mechanical behaviour appears to be very complex, especially in the domain of small effective stresses, close to the overburden effective stresses.

The term 'remoulded' is used to describe the sediment in which the bonding between particles has been intentionally destroyed in the laboratory. The behaviour of the reconstituted material at $w_{\text {sat }}=1.5 w_{\mathrm{L}}$ will thus depend solely on the applied stress tensor (e.g. Biarez \& Hicher, 1994), However, this point is still under discussion. Indeed, Hong et al. $(2010,2012)$ showed that this is true only when the stress applied is higher than a characteristic stress, namely the remoulded stress. Its behaviour will give access to the intrinsic mechanical properties (Biarez \& Favre, 1977; Burland, 1990), and will provide a framework for the evolution of the behaviour of the in situ soil, designated in this paper by the term 'natural sediment'. Many authors have shown that the phenomenological behaviour of natural sediments depends strongly on the deposition history (Been \& Sills, 1981; Pane \& Schiffman, 1985; Blewett et al., 2001). The influence of the material structure, including fabric and bonding (Mitchell, 1976), can be approximated by comparing the different responses of the natural structured sediment and the remoulded sediment under equal loading. The natural sediment behaviour has been described by Leroueil et al. (1979) as a destructuration phenomenon. Along the oedometric path, for instance, the initial soil structure is gradually destroyed, and the experimental curves tend to converge at high stresses towards the remoulded behaviour represented by the intrinsic compression line (Burland, 1990). Clayey material structuration has been quantified by Cotecchia \& Chandler $(1997,2000)$ using the sensitivity parameter $S_{\mathrm{t}}$ (Skempton \& Northey, 1952) as a normalising parameter for the structure. Thus the evolution of $S_{\mathrm{t}}$ may be used to describe the destructuration phenomenon (see e.g. the destructuration law by Baudet \& Ho, 2004).

However, the literature offers few results at the microstructural level, and the local mechanisms which occur under mechanical loading are not well known. Most of the available results concern remoulded and reconsolidated clays by means of various experimental techniques and along various loading paths. Using polarised light microscopy to study the kaolin fabric under direct shear, Morgenstern \& Tchalenko (1967) showed a strong reorientation of the particles in the principal strain directions. Along oedometric paths, X-ray diffraction analyses (Martin \& Ladd, 1975; Guillot et al., 2001) and scanning electron microscopy (SEM) observations (Pusch, 1970; Delage \& Lefebvre, 1984) have highlighted the development of a gradual structural anisotropy. Recently, on the same stress path, Delage (2010) provided a description of microstructural changes during compression that extends to various sensitive clays. The study demonstrated that microstructural variation could be precisely described by the pore-size distribution changes with progressive and ordered collapse of pores ranging from the largest to the smallest. Along triaxial paths, Hicher et al. (2000), used SEM image analysis to show the fabric evolution of two saturated clayey materials: a kaolin and a bentonite. The creation of anisotropy was thus highlighted, demonstrating that the mechanical behaviour is strongly dependent on the changes occurring at the local particle scale. Also along triaxial paths, Hattab \& Fleureau $(2010,2011)$ linked the orientation mechanism of a kaolin microstructure to the macroscopic stress state. 
The goals of the present paper are: (a) to highlight the microstructure effect in the macroscopic behaviour by an experimental study of the response of natural intact samples whose properties, especially in the first few metres, have proven to be quite complex (Puech et al., 2005), and to analyse the differences observed on the remoulded specimens along different loading paths; (b) to attempt to explore, at the microstructural level, the mechanisms generating the macroscopic strains. The analysis will consist of examining, first, the remoulded samples and, second, the intact ones, with a special focus on cementation damage. Investigations have been made on specimens subjected to different mechanical loading paths: oedometric path, isotropic path, constant-volume triaxial path (undrained tests) and constant lateral effective stress path (conventional drained test).

\section{CLAY PROPERTIES}

\section{Gulf of Guinea clay}

The available samples come from a core $17 \mathrm{~m}$ long, taken at a depth of $700 \mathrm{~m}$ in the GoG. It was provided cut into sections $1 \mathrm{~m}$ long and numbered precisely by depth. These core sections were first stacked vertically in a freezer in order to maintain a good quality of samples, and then removed for the testing and cut into several specimens, also precisely numbered. The section between the depths of $9.0 \mathrm{~m}$ and $10 \mathrm{~m}$, for example, is numbered $\left[\begin{array}{ll}X-9 & 10\end{array}\right]$, where $X$ is the number of samples in this section, classified from top to bottom. For each sample, quality was systematically verified according to the Lunne et al. (1998) criteria, as shown later. The material appears to be a saturated, very plastic dark grey clay, with many shell fragments visible to the naked eye. Extensive studies on the index properties of the material have been performed and published by various authors (e.g. Puech et al., 2005; Favre \& Hattab, 2008; Hattab \& Favre, 2010). Identification of the GoG clay properties through the Atterberg limits represented in the $\left(w_{\mathrm{L}}-I_{\mathrm{p}}\right)$ diagram (Fig. 1) seems to indicate that these sediments are smectite-type clays. X-ray diffraction analysis performed at various locations of the core by Thomas et al. (2005) showed that the clay fraction is about $40-60 \%$, with approximately $50 \%$ of kaolinite and $15-25 \%$ of smectite. The organic substance content is $6 \%$, and the carbonate content is between $5 \%$ and 15\%. Hattab \& Favre (2010) showed that sensitivity globally varies around 6-8, with a few peaks of high sensitivity (as instance between $5 \mathrm{~m}$ and $6 \mathrm{~m}$ depth with
$S_{\mathrm{t}}=19$, or around $10 \mathrm{~m}$ depth with a measured sensitivity of 32 ).

Nature and arrangement properties of aggregates

The 'aggregate' notion, used in this paper, represents clayey particles, combined with organic and siliceous elements. As an example, Fig. 2 shows an organo-mineral aggregate composed of a 'foliage' of smectite particles where some pyrite spheroids are fixed. The 'nature of aggregate' properties may be represented by the Atterberg limits $w_{\mathrm{L}}, w_{\mathrm{P}}$ and $I_{\mathrm{P}}$, but also by the corresponding void ratios $e_{\mathrm{L}}=w_{\mathrm{L}} \gamma_{\mathrm{s}} / \gamma_{\mathrm{w}}$ and $e_{\mathrm{P}}=w_{\mathrm{P}} \gamma_{\mathrm{s}} / \gamma_{\mathrm{w}}$ for the saturated soil. Liquid limits have been determined from the fall cone method, which has proved to be more reliable than the Casagrande method (Koumoto \& Houlsby, 2001). The results obtained show that $w_{\mathrm{L}}$, varies from $110 \%$ to $160 \%$, with especially high values at the surface of the seabed, and the plastic limit $w_{\mathrm{P}}$ from $30 \%$ to $90 \%$ (Table 1 ).

The arrangement of the aggregates and its changes are represented by the natural water content variation $w_{\text {nat }}$ (or the natural void ratio $e$ ), as well as by the vertical effective stress $\sigma_{\mathrm{v}}^{\prime}$; the latter has been calculated on the basis of $\gamma^{\prime}$, the submerged unit weight, taking $\gamma_{\mathrm{s}} / \gamma_{\mathrm{w}}=2 \cdot 60$, where $\gamma_{\mathrm{s}}$ is the unit weight of the solid matter (Table 1) and $\gamma_{\mathrm{w}}$ that of the seawater. The $w_{\text {nat }}$ profile in Fig. 3 with the corresponding values of $w_{\mathrm{L}}$ and $w_{\mathrm{P}}$ shows that the values of $w_{\text {nat }}$

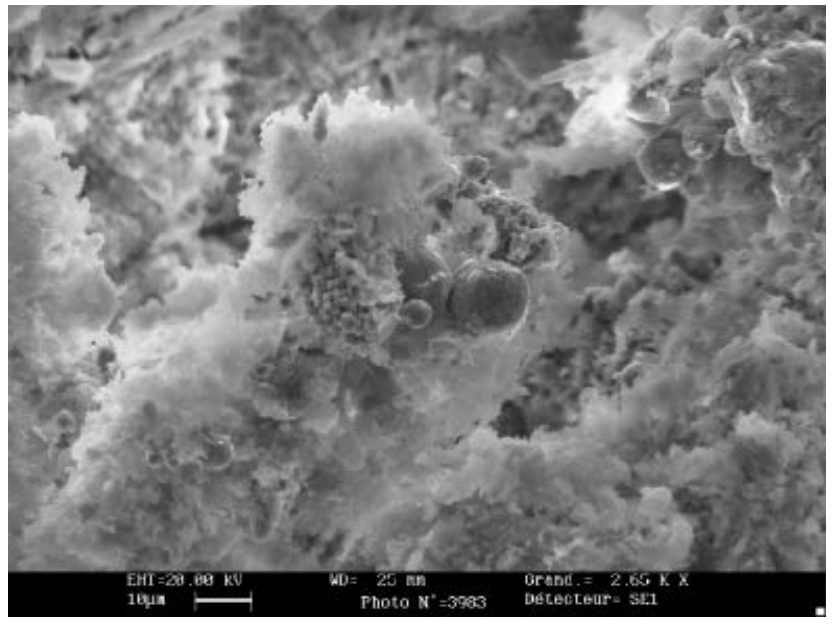

Fig. 2. Example of organo-mineral aggregate found towards $10 \mathrm{~m}$ depth

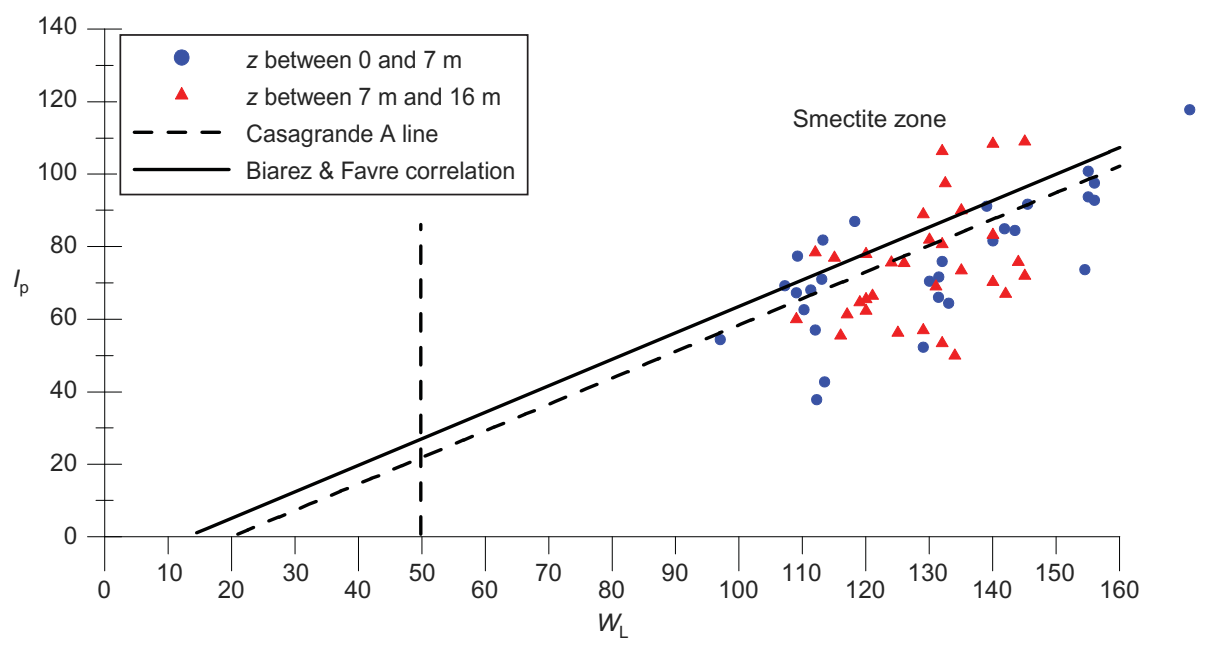

Fig. 1. Experimental results for GoG clay in $w_{\mathrm{L}}-I_{\mathrm{P}}$ plot 
Table 1. Gulf of Guinea clay characteristics

\begin{tabular}{l|c}
\hline Property & Value \\
\hline$w_{\mathrm{L}}: \%$ & $160-110$ \\
$w_{\mathrm{P}}: \%$ & $90-30$ \\
$\gamma_{\mathrm{s}}: \mathrm{kN} / \mathrm{m}^{3}$ & $26 \cdot 5$ \\
$\sigma_{\mathrm{v} 0}^{\prime}: \mathrm{kPa}$ & $0 \cdot 7-55 \cdot 7$ \\
$w_{\text {nat }}: \%$ & $130-170$ \\
$e_{0}$ & $2 \cdot 5-4 \cdot 5$ \\
$\sigma_{\mathrm{p}}^{\prime}: \mathrm{kPa}$ & $18-40$ \\
\hline
\end{tabular}

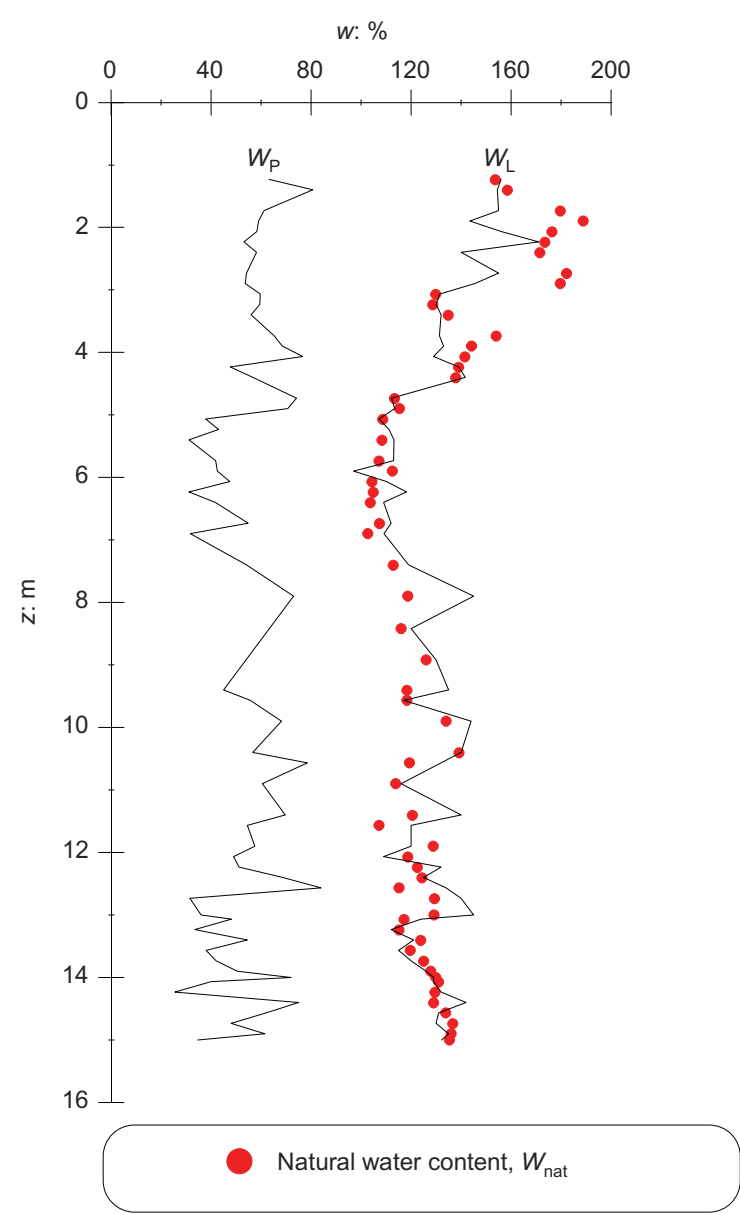

Fig. 3. Natural water content and index properties of GoG clay (Hattab \& Favre, 2010)

are very close to the liquid limit and sometimes higher, especially at the surface of the seabed, with values up to $180 \%$. An early development of bonds between clay aggregates during the sedimentation process may be assumed to explain these high values of the natural water content (as shown by various authors: e.g. Pusch, 1970; Mitchell, 1976; Biarez et al., 1998; Blewett et al., 2001).

\section{EXPERIMENTAL SET-UP AND TEST PROCEDURES}

Mechanical testing

The experimental set-up used for the mechanical tests consists of a triaxial cell, similar to the Bishop-Wesley cell (Bishop \& Wesley, 1975), and three pressure-volume controllers for control and data acquisition, which ensure control of the radial and axial stresses (generated by the displacement of a jack at the bottom part of the cell) and of the back-pressure, as well as volume change, axial force and axial displacement measurements. A software program (Piltriax, developed by Hattab \& Hicher, 2004) provides test automation and data acquisition. Triaxial tests were carried out on saturated clay samples, both intact and remoulded, the first step consisting in checking the quality of the saturation by measuring Skempton's (1954) coefficient $B=\Delta u / \Delta \sigma_{3} \approx 100 \%$. Back-pressure was set at $600 \mathrm{kPa}$ for undrained tests and at $400 \mathrm{kPa}$ for drained tests.

(a) Preparation of natural clay specimens: specimens with height $h_{0}=53 \mathrm{~mm}$ and diameter $d_{0}=35 \mathrm{~mm}$ were cut at different depths in subsections prior to extraction from the core. Using the criteria for evaluating sample disturbance established by Lunne et al. (1998) for plastic clays, where $I_{\mathrm{P}}$ varies from $10 \%$ to $55 \%$ (Table 2 ), each specimen was systematically analysed. Only those whose state was classified as 'very good' to 'good' according to the criteria listed in Table 2 were selected for study of their mechanical behaviour.

(b) Preparation of remoulded clay specimens: a sample was first extracted from a subsection at a given depth of the core. It was gradually and gently mixed with distilled and de-aired water in order to obtain a slurry with a water content $w=1.5 w_{\mathrm{L}}$. The slurry was then poured into a rigid cylindrical mould (diameter $=40 \mathrm{~mm}$ ) and consolidated under a vertical stress of $80 \mathrm{kPa}$. Finally, the sample was cut into cylindrical specimens with height $h_{0}=53 \mathrm{~mm}$ and diameter $d_{0}=35 \mathrm{~mm}$.

The cylindrical specimens (remoulded or natural) were then placed in the triaxial cell, with an anti-frictional system allowing drainage at the two ends. The anti-frictional device is a 'sandwich' consisting of two circular smooth plates lubricated by grease and latex layers. This procedure is often considered as an optimum compromise to maintain the homogeneity of the sample up to large strains, by significantly reducing the friction at the sample ends, as shown by Hicher (1985) and Lade \& Tsai (1985) and more recently by Frost \& Yang (2003).

All the tests on remoulded and intact specimens are listed in Table 3. Oedometric and isotropic tests were performed by increasing the load step by step up to the chosen stress. Because of the difference in permeability between the remoulded and intact sediment samples, the duration of each step was $40 \mathrm{~h}$ for the remoulded sediment and $30 \mathrm{~h}$ for the intact sediment.

Microstructural investigations

MIP tests. Mercury intrusion porosimetry (MIP) analysis (using a Micromeritics AutoPore IV 9500) provides an

Table 2. Criteria by Lunne et al. (1998) for evaluation of sample disturbance

\begin{tabular}{l|c|c|c|c}
\hline \multirow{2}{*}{ OCR } & \multicolumn{4}{|c}{$\Delta e / e_{0}$} \\
\cline { 2 - 5 } & Very good to excellent & Good to fair & Poor & Very poor \\
\hline $1-2$ & $<0.04$ & $0 \cdot 04-0 \cdot 07$ & $0 \cdot 07-0 \cdot 14$ & $>0 \cdot 14$ \\
$2-4$ & $<0.03$ & $0 \cdot 03-0 \cdot 05$ & $0 \cdot 05-0 \cdot 1$ & $>0 \cdot 10$ \\
\hline
\end{tabular}


Table 3: Tests on natural and remoulded GoG sediments

\begin{tabular}{|c|c|c|c|c|c|c|c|c|c|}
\hline Sample & Sample no. & Loading & $z: \mathrm{m}$ & $\begin{array}{c}\sigma_{\mathrm{v} 0}^{\prime}(\text { in situ): } \\
\mathrm{kPa}\end{array}$ & $\begin{array}{c}e_{0} \\
\text { (initial) }\end{array}$ & $\begin{array}{c}\text { Stress: } \\
\mathrm{kPa}\end{array}$ & MIP test & $\mathrm{e}$ & $e_{\text {poro }}$ \\
\hline Conso_Rem80 & $2-56$ & Consolidometer & $5 \cdot 25$ & - & - & 80 & Conso_Rem80 & $2 \cdot 54$ & $2 \cdot 10$ \\
\hline oedo-Rem & $5-89$ & Oedometric & $8 \cdot 65$ & - & $2 \cdot 54$ & 1000 & oed_Rem 1000 & $1 \cdot 39$ & $1 \cdot 26$ \\
\hline iso-Rem2 & $5-1011$ & Isotropic & $10 \cdot 65$ & - & $2 \cdot 57$ & 600 & - & - & - \\
\hline iso-Rem1 & $5-1011$ & Isotropic & $10 \cdot 65$ & - & $2 \cdot 69$ & 1000 & iso_Rem1000 & $1 \cdot 55$ & 1.09 \\
\hline dr100_Rem & $5-1011$ & Triax-drained & $10 \cdot 65$ & - & $2 \cdot 59$ & 100 & triax_Rem 100 & 1.97 & $2 \cdot 15$ \\
\hline dr200_Rem & $5-1112$ & Triax-drained & $11 \cdot 65$ & - & $2 \cdot 59$ & 200 & triax_Rem 200 & $1 \cdot 91$ & $1 \cdot 14$ \\
\hline dr600_Rem & $2-56$ & Triax-drained & $5 \cdot 25$ & - & $2 \cdot 49$ & 600 & triax_Rem600 & $1 \cdot 36$ & $0 \cdot 87$ \\
\hline undr200_Rem & $6-1112$ & Triax-undrained & $11 \cdot 65$ & - & $2 \cdot 58$ & 200 & - & - & - \\
\hline Natural sediment & $6-910$ & - & $9 \cdot 65$ & $36 \cdot 5$ & $3 \cdot 28$ & - & Natural sediment & $3 \cdot 28$ & $3 \cdot 07$ \\
\hline oedo-nat1 & $5-910$ & Oedometric & $9 \cdot 65$ & $36 \cdot 5$ & $3 \cdot 28$ & 1000 & oed_nat1000 & $1 \cdot 33$ & $1 \cdot 21$ \\
\hline oedo-nat2 & $2-1617$ & Oedometric & $16 \cdot 25$ & 88 & $3 \cdot 2$ & 1000 & - & - & - \\
\hline iso-nat1 & $5-67$ & Isotropic & $6 \cdot 65$ & $22 \cdot 5$ & $2 \cdot 99$ & 900 & iso_nat 900 & $1 \cdot 77$ & $1 \cdot 22$ \\
\hline iso-nat2 & $5-1011$ & Isotropic & $10 \cdot 65$ & $40 \cdot 35$ & $3 \cdot 06$ & 600 & - & - & - \\
\hline dr10-nat & $5-12$ & Triax-drained & $1 \cdot 65$ & $3 \cdot 67$ & $4 \cdot 49$ & 10 & - & - & - \\
\hline dr40-nat & $5-89$ & Triax-drained & $8 \cdot 65$ & $30 \cdot 9$ & $3 \cdot 3$ & 40 & triax_nat40 & $2 \cdot 72$ & $2 \cdot 72$ \\
\hline dr60-nat & $5-67$ & Triax-drained & $6 \cdot 65$ & $24 \cdot 80$ & $2 \cdot 53$ & 60 & - & - & - \\
\hline dr200-nat & $5-1011$ & Triax-drained & $10 \cdot 65$ & $40 \cdot 35$ & $3 \cdot 03$ & 200 & triax_nat 200 & 1.94 & 1.66 \\
\hline dr600-nat & $5-67$ & Triax-drained & $6 \cdot 65$ & $24 \cdot 80$ & $2 \cdot 53$ & 600 & triax_nat600 & $1 \cdot 44$ & $1 \cdot 15$ \\
\hline undr14-nat & $3-45$ & Triax-undrained & $4 \cdot 25$ & $13 \cdot 8$ & $3 \cdot 18$ & 14 & - & - & - \\
\hline undr33-nat & $4-89$ & Triax-undrained & $8 \cdot 25$ & $30 \cdot 9$ & $3 \cdot 3$ & 33 & - & - & - \\
\hline undr40-nat & $3-89$ & Triax-undrained & $8 \cdot 25$ & $30 \cdot 9$ & $3 \cdot 3$ & 40 & - & - & - \\
\hline undr116-nat & $4-89$ & Triax-undrained & $8 \cdot 25$ & $30 \cdot 9$ & $3 \cdot 3$ & 116 & - & - & - \\
\hline
\end{tabular}

indication of the local porosity of the sample, as well as an image of the pore-size distribution. The principle is based on the Laplace-Young law, which connects the capillary pressure $P_{\mathrm{c}}$ to the capillary radius $r$ according to

$$
P_{\mathrm{c}}=\frac{2 \gamma \cos \theta}{r}
$$

where $\theta$ is the contact angle between the liquid mercury and the solid surface (for the present study $\theta=140^{\circ}$ ), and $\gamma$ is the mercury surface tension $(\gamma=0.482 \mathrm{~N} / \mathrm{m}$, Delage \& Lefebvre, 1984).

Thus, by varying the pressure applied to the mercury, and by measuring the volume injected within the specimen, the pore size can be obtained as a function of the mercury intrusion volume. The highest intrusion pressure that can be applied is $200 \mathrm{MPa}$, corresponding to pores about $6 \mathrm{~nm}$ in diameter.

MIP tests require that the pore volume be accessible to the injected mercury. It is therefore necessary before injection to remove the pore water from the samples without disturbing the microstructure. For this purpose, the method used consisted in freeze-drying small samples, taken from the tested specimens at the end of the mechanical tests after unloading. These small samples, of about $1 \mathrm{~cm}^{3}$ in volume, were extracted from the tested specimens by simple cutting. The samples, initially saturated, were then freeze-dried according to the method by Delage \& Pellerin (1984); a sublimation of ice was then carried out inside a freeze-dryer of compact flexi-dry type.

SEM observations. The same preparation of samples was used for SEM observations, but with a higher degree of care during cutting. The small samples, parallelepiped in shape and of about $1 \mathrm{~cm}^{3}$ in volume, were extracted from the specimen and marked according to their orientation with respect to the direction of the principal stresses $\sigma_{1}$ and $\sigma_{3}$ applied during the tests (Fig. 4). The cross-sections used for the SEM observations were obtained by fracturing the frozen samples in the longitudinal direction with a sharp blow dealt by means of a blade. The same orientation of the cutting plane with respect to the direction of $\sigma_{1}$ and $\sigma_{3}$ was maintained during the various phases of preparation and observation.

\section{MECHANICAL BEHAVIOUR OF GoG CLAY}

Mechanical behaviour along oedometric and isotropic loading paths

The results of oedometric and isotropic loadings on natural specimens (oedo-nat and iso-nat) and on remoulded reconsolidated specimens (oedo-Rem and iso-Rem) are presented in Fig. 5. The oedometric path of the natural sediment oedo-nat (Fig. 5(a)) shows a small reduction in void ratio at the beginning of the loading and then a very sharp increase at a vertical effective stress of $\sigma_{\mathrm{v}}^{\prime}=63 \mathrm{kPa}$ (denoted as maximum strength), which is higher than the overburden effective stress $\left(\sigma_{\mathrm{v} 0}^{\prime}=36.5 \mathrm{kPa}\right)$. The point corresponding to this threshold is located above the stressstrain curve of the normally consolidated remoulded sediment. Thus, a structure with a special configuration of 'aggregates' linked together by light bonding 'glue' may be assumed as a first approach to explain this macroscopic behaviour. During one-dimensional compression, the presence of these bonds leads to an overestimation of the preconsolidation stress $\sigma_{\mathrm{p}}^{\prime}$ by preventing the 'grains' from moving freely and the assembly to deform, as would be the case with remoulded reconstituted clay.

Afterwards, the oedometric path gradually joins the path characterising the behaviour of the normally consolidated remoulded specimen oedo-Rem. The detailed study carried out on the same material by Hattab \& Favre (2010) describes the behaviour of the GoG sediment, especially along the oedometric path.

In the $\log p^{\prime}-e$ plane, the isotropic path iso-nat (Fig. 5(b)) also presents a threshold for the effective isotropic stress $p^{\prime}=110 \mathrm{kPa}$, which corresponds to the beginning of bond breakage; it then tends to converge gradually towards the normally consolidated isotropic behaviour of the remoulded reconsolidated sediment iso-Rem. Compared with the 


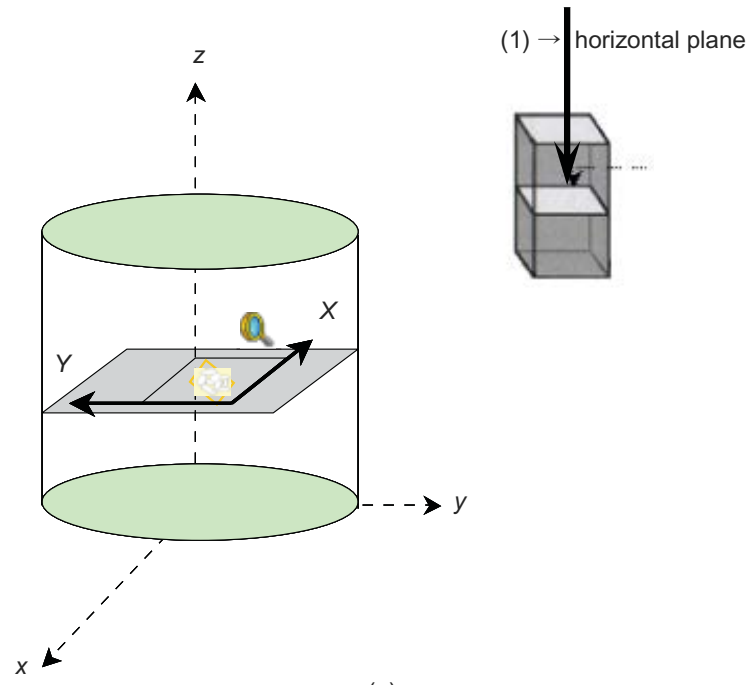

(a)

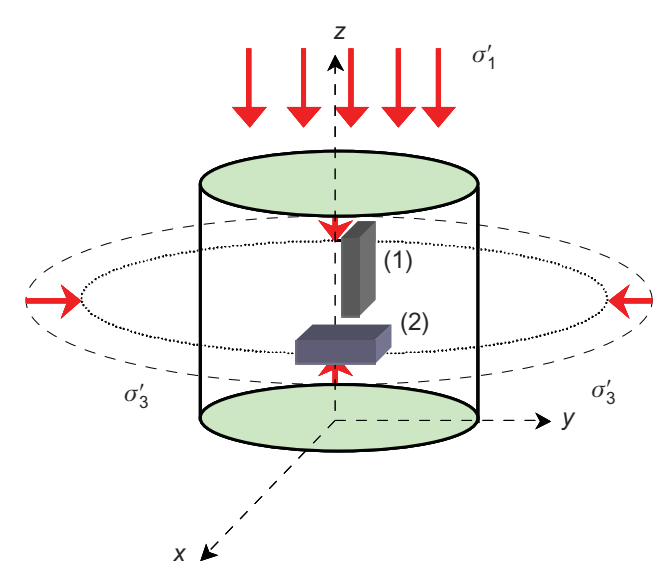

(b)

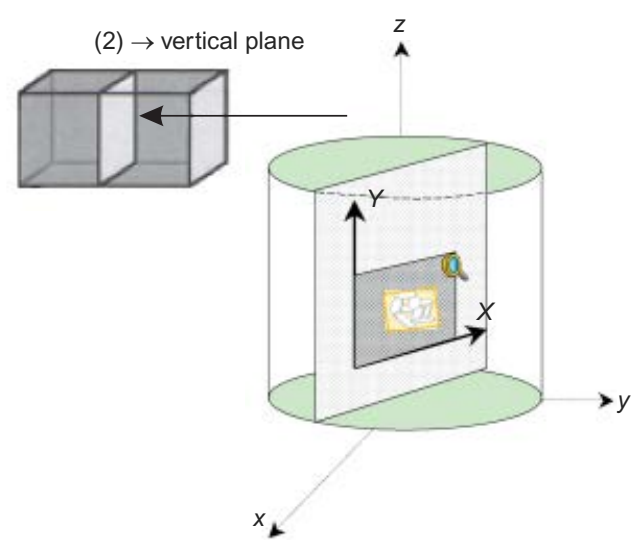

(c)

Fig. 4. Location of specimens for SEM observations: (a) horizontal observation plane; (b) samples for observation and stress state; (c) vertical observation plane

oedometric path, the isotropic path curvature is evidently less pronounced. At the isotropic effective stress $p^{\prime}=600 \mathrm{kPa}$, the results show that the remoulded behaviour has not been reached. This means that the deviatoric part of the stress, present in the oedometric loading, induces more rapid damage, the degradation of the natural sediment being more pronounced. On the other hand, the compressibility of the remoulded sediment along both oedometric and isotropic paths is quite similar.

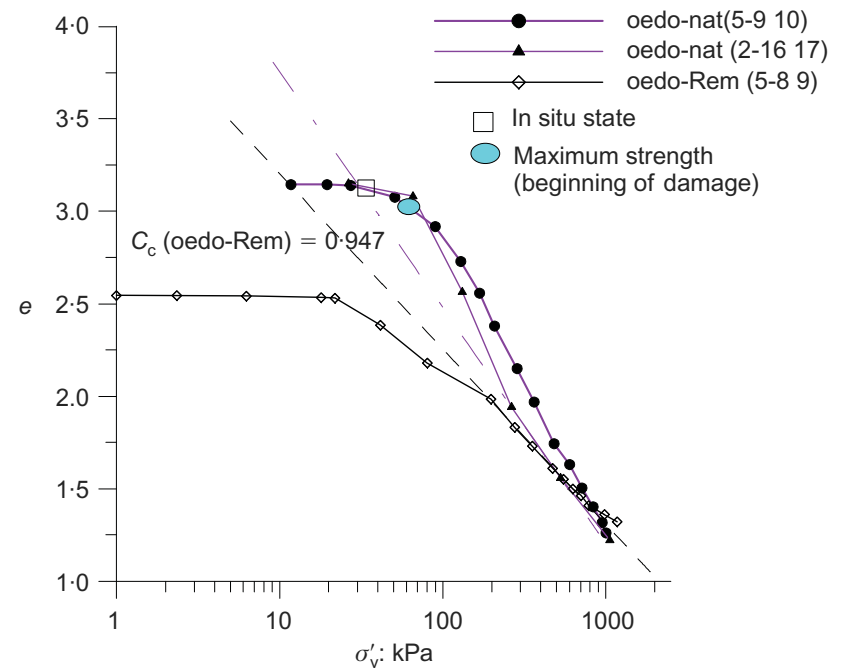

(a)

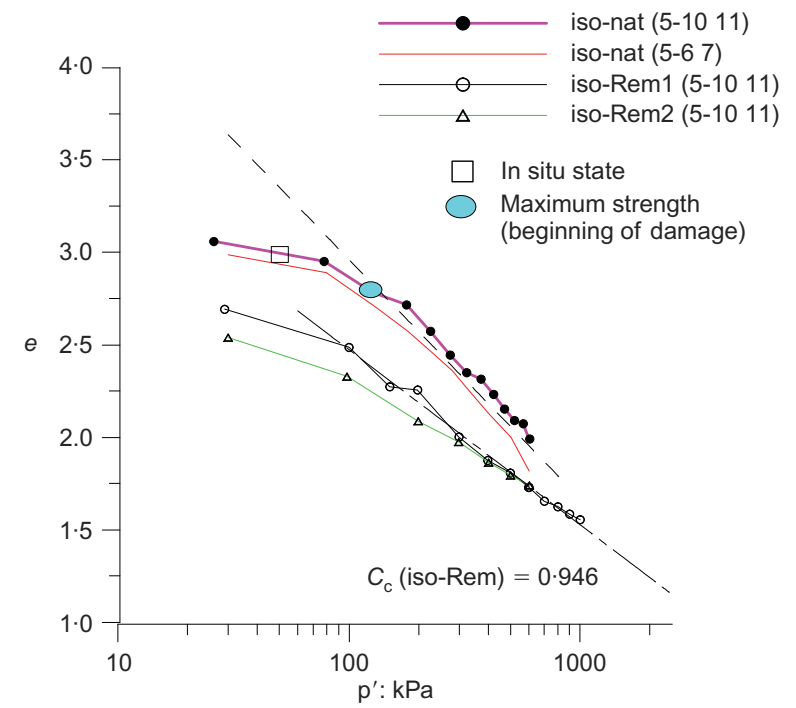

(b)

Fig. 5. (a) Oedometric and (b) isotropic paths on GoG clay

Mechanical behaviour of remoulded and intact GoG sediment along triaxial paths

All the results on intact and remoulded specimens are plotted in the $\varepsilon_{1}-q$ and $\varepsilon_{1}-\varepsilon_{\mathrm{v}}$ or $\Delta u$ planes in Fig. 6, and in the $p^{\prime}-q$ and $\log p^{\prime}-e$ planes in Figs $7(\mathrm{a}), 7(\mathrm{~b})$ and 8 . Specimen characteristics and test conditions are summarised in Table 3.

Four triaxial tests were performed on remoulded specimens. Three of them were performed under drained conditions, with a $0.012 \mathrm{~mm} / \mathrm{h}$ rate of shearing (dr100_Rem, dr200_Rem and dr600_Rem, consolidated under isotropic stresses $p_{0}^{\prime}=100 \mathrm{kPa}, 200 \mathrm{kPa}$ and $600 \mathrm{kPa}$ respectively) and one test under undrained conditions (undr200_Rem, with a $0.06 \mathrm{~mm} / \mathrm{h}$ rate of shearing) with an isotropic consolidation stress $p_{0}^{\prime}=200 \mathrm{kPa}$.

Triaxial tests on intact GoG sediment were performed under drained (with a $0.02 \mathrm{~mm} / \mathrm{h}$ rate of shearing) and undrained (with a $0.1 \mathrm{~mm} / \mathrm{h}$ rate of shearing) conditions, with the isotropic consolidation stress $p_{0}^{\prime}$ varying from $10 \mathrm{kPa}$ to $600 \mathrm{kPa}$ for drained tests, and from $14 \mathrm{kPa}$ to $112 \mathrm{kPa}$ for undrained tests.

Throughout the study of remoulded GoG sediment, an attempt was made to approach an average behaviour, which could be considered to be valid throughout the core, and 


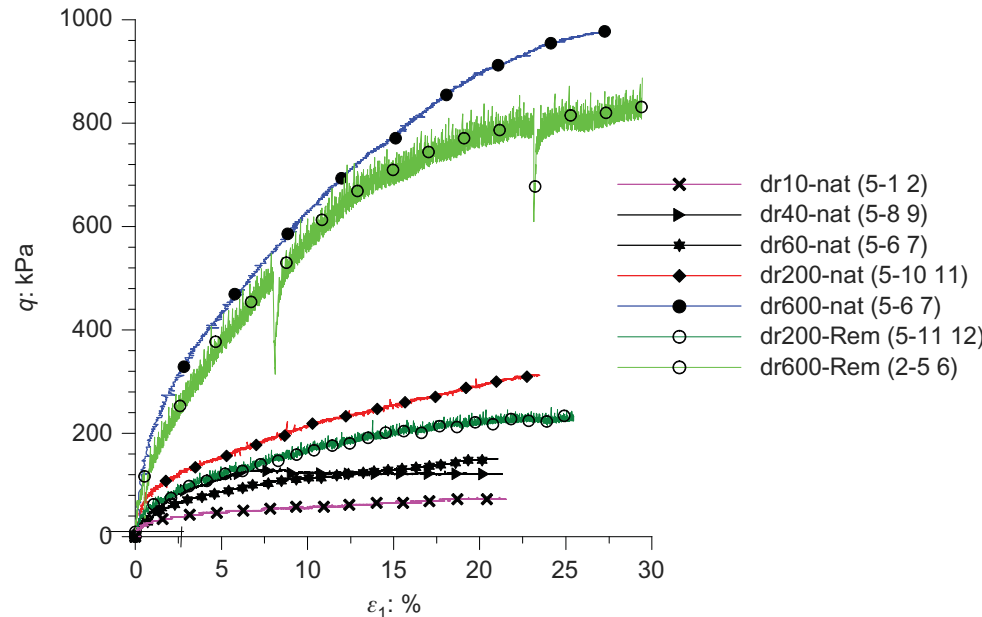

(a)

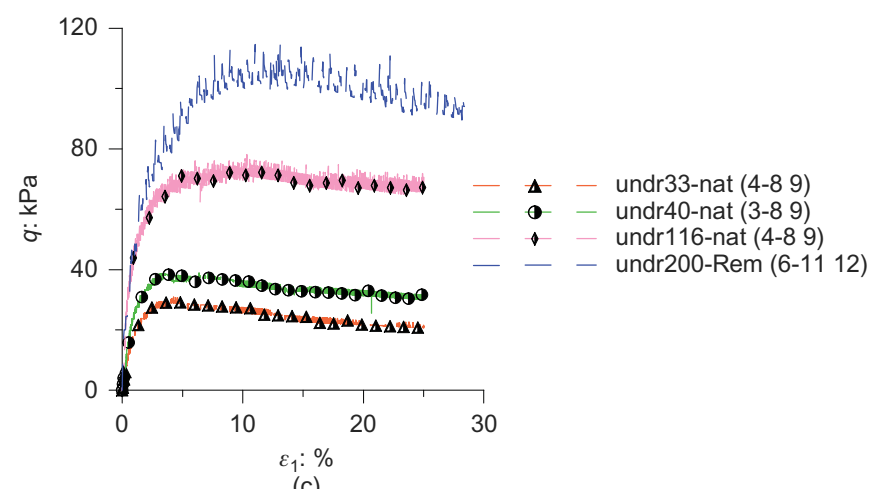

(c)

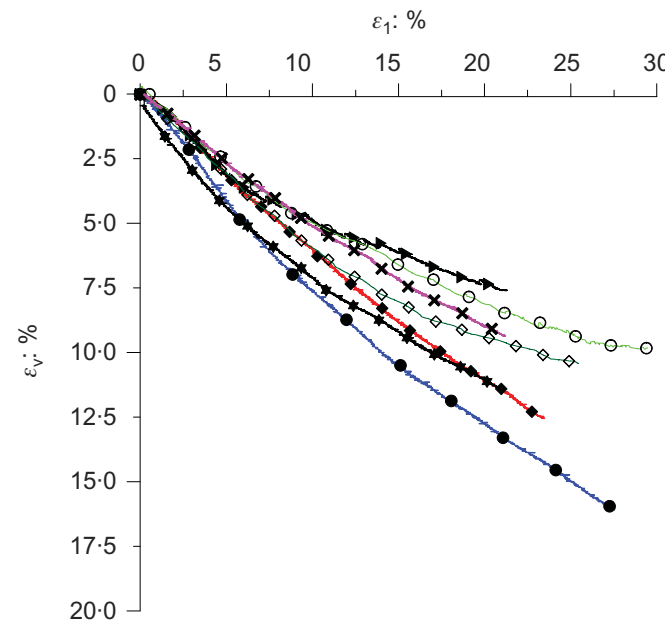

(b)

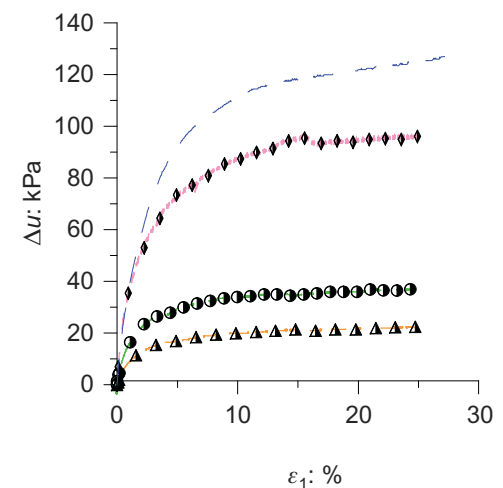

$\varepsilon_{1}: \%$
(d)

Fig. 6. Triaxial loading: (a) $\varepsilon_{1}-q$ plane, drained condition; (b) $\varepsilon_{1}-\varepsilon_{\mathrm{v}}$ plane, drained condition; (c) $\varepsilon_{1}-q$ plane, undrained condition; (d) $\varepsilon_{1}-\Delta u$ plane, undrained condition

which may be regarded as intrinsic to the material (Burland, 1990). In this way, the ISL-Rem (isotropic state line) determined for the remoulded material represents the isotropic path of the remoulded normally consolidated GoG clays (Fig. 5(b)). Drained and undrained paths make it possible to try to approach critical state (Schofield \& Wroth, 1968), which can be considered close to a straight line with a slope equal to 1 in the $p^{\prime}-q$ plane for the remoulded sediment $\left(M=1\right.$, corresponding to a friction angle close to $\left.25 \cdot 4^{\circ}\right)$, and close to the line that can be associated to the CSL (critical state line), parallel to the isotropic path (ISL-Rem) in the $\log p^{\prime}-e$ plane (Fig. 7). The significant distance between the ISL-Rem and the CSL $(\Delta e=0 \cdot 25)$ shows the large capacity of the remoulded sediment to contract during triaxial loading. It is not unlikely that this high contractance includes the deformability or breakage of some organic elements (Hattab \& Favre, 2010) present in the sediment, whose role in this case becomes very significant. For instance, in mineral clays of kaolin type, $\Delta e=0.05$ (Hattab \& Hicher, 2004), leading to a much lower volumetric strain along a drained triaxial path.

The behaviour of the intact GoG sediment, presented in the same planes, shows some differences with respect to the behaviour of the remoulded sediment. However, the variation of the initial void ratio can be noted ranging from 2.53 to 4.49 (Fig. 7(c)). Two domains of behaviour can be distinguished, as follows.

The first is a small isotropic consolidation stress domain, where the initial structure of the material remains fairly undisturbed by the isotropic loading. The results highlight, for both undrained and drained loadings, the existence of a structure that has not yet been damaged by the initial isotropic loading. Along the undrained path a cohesion appears as a peak, especially pronounced in the undr33-nat and undr40-nat curves, in the $\varepsilon_{1}-q$ and $p^{\prime}-q$ planes (Fig. 6). This peak seems to be more difficult to obtain in the case of drained paths except for the dr40-nat path (Fig. 6). This kind of behaviour is often observed in marine clays (e.g. Swedish soft clay; Axelsson et al., 1994). The analysis in the $\log p^{\prime}-$ $e$ plane shows that, at the beginning of the loading, the dr10-nat and dr40-nat curves (and dr60-nat to a lesser extent) follow approximately a straight line (Fig. 7(b)) before changing direction. This shows that the structure of the intact specimens was not significantly affected by the initial isotropic loading. When the isotropic consolidation stress increases (the undr116-nat and dr60-nat paths; Figs 7(b) and 8), a damage phenomenon starts to appear during the isotropic loading, and continues to develop all along the triaxial path. The curves then reach a plateau in the $\varepsilon_{1}-q$ plane (Fig. 6), associated in the undrained case with the stabilisation of the pore pressure. In drained tests, the behaviour is contractant, and only the dr40-nat curve, which exhibits a deviatoric peak, reaches stabilisation in both the $\varepsilon_{1}-q$ and $\varepsilon_{1}-\varepsilon_{\mathrm{v}}$ planes. The dr10-nat and dr60-nat curves show a continuous increase in deviatoric stress and volumetric strain.

The second type of behaviour is a higher isotropic consolidation stress domain (the cases of dr200-nat and dr600nat under a drained path), where the damage of the sediment structure begins during the isotropic loading, and continues all along the triaxial path. The intact specimen curves are located close to, but systematically above, those of the 


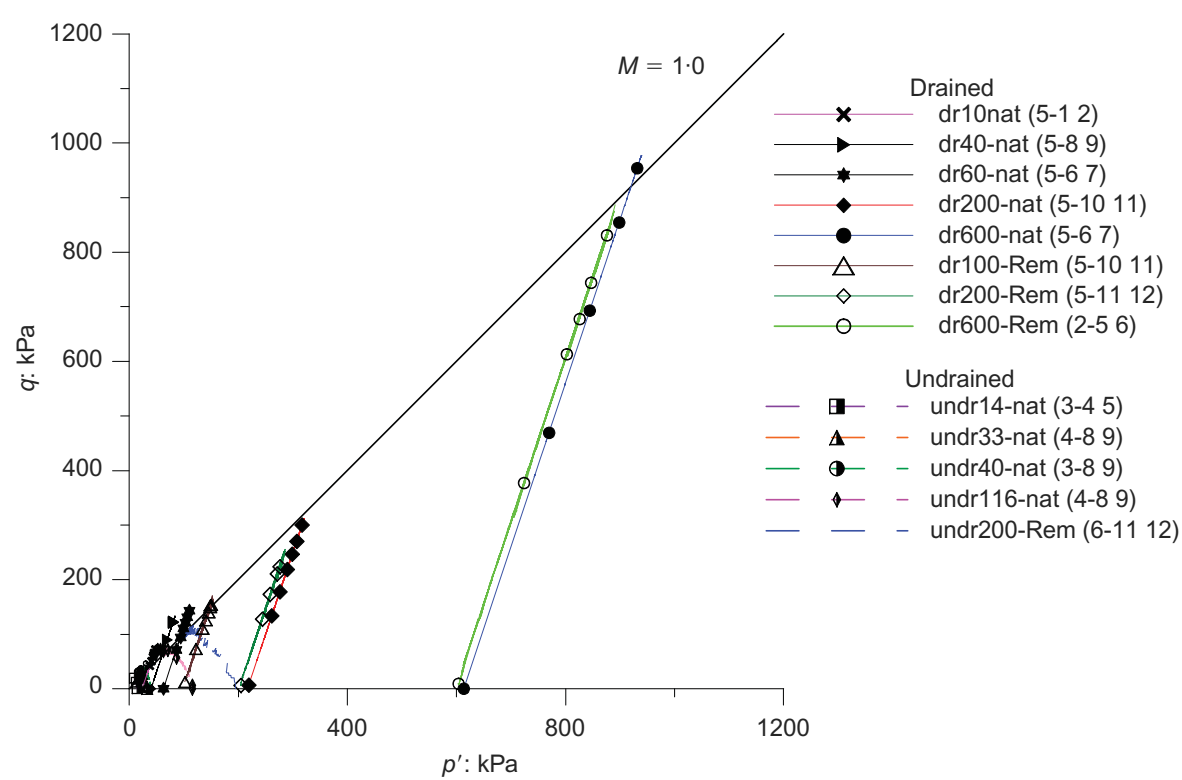

(a)
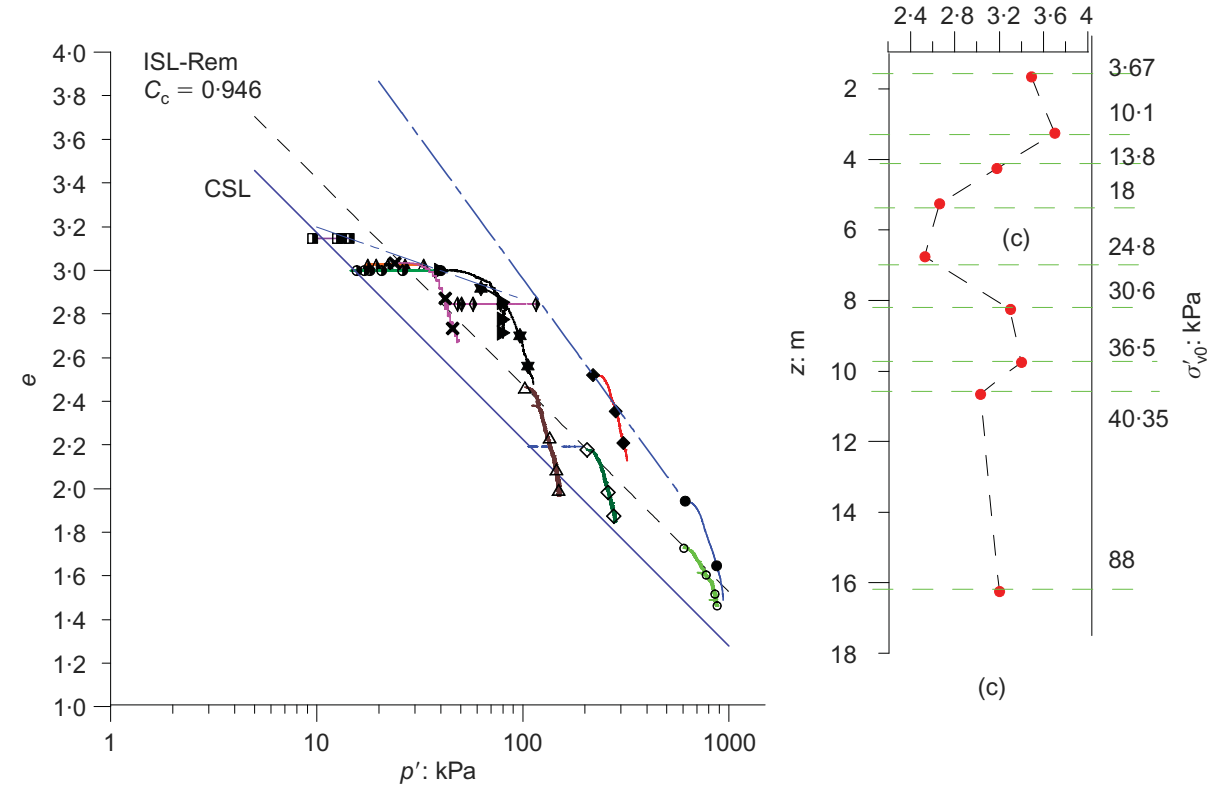

(c)

(b)

Fig. 7. Global behaviour of sediment: (a) plotted in $p^{\prime}-q$ plane; (b) plotted in $\log p^{\prime}-e$ plane; (c) in situ state

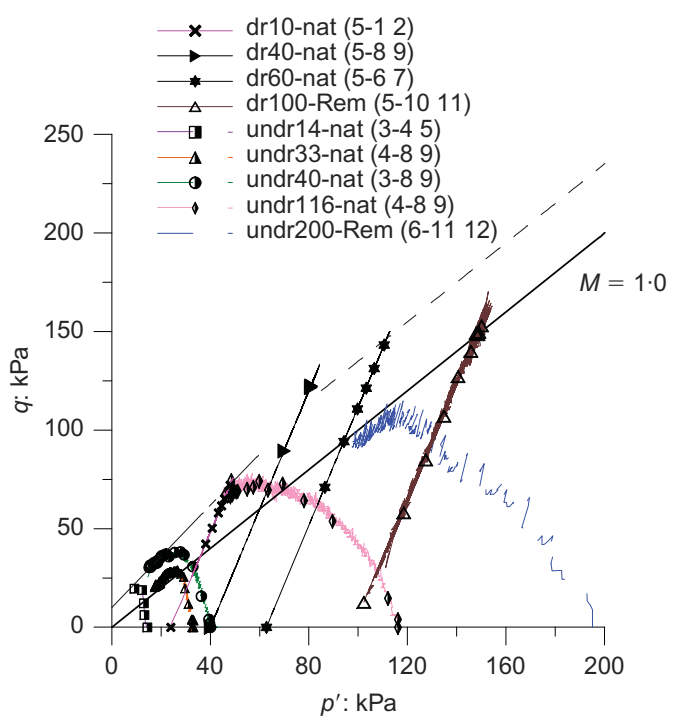

Fig. 8. Triaxial tests in low-stresses domain remoulded specimens in the $\varepsilon_{1}-q$ plane (Fig. 6), meaning that the strength of the intact sediment is greater. The intact sediment contraction is, on the other hand, more pronounced and does not stabilise at the end of the loading. One can note that the wide range in initial void ratios discussed above, which correspond to different structural organisations in the initial state of the material (sensitivity), implies that specimens need different levels of shear loading for stabilisation. This larger strength leads in the $p^{\prime}-q$ plane in Fig. 7 (a) to a maximum strength locus located above the $M$ line as defined by the remoulded behaviour, which seems to produce a very weak apparent cohesion (about $10 \mathrm{kPa}$ ) for small isotropic consolidation stresses (Fig. 8).

It is important to understand how, at the microscopic scale, the sediment structure evolves during loading, and whether the assumption proposed as a holistic approach by Biarez (cementation linking 'grains' or 'aggregates') is justified. The investigations of the microstructure were performed by MIP, complemented by SEM images taken in the same states of stresses and strains. 


\section{MICROSTRUCTURE ANALYSIS}

Microstructural evolution of natural and remoulded specimens

The microstructural approach consists of analysing the microstructural evolution of natural and remoulded specimens extensively under different loading conditions. Observations were made in the initial state, after oedometric loading $\left(\sigma_{\mathrm{v}}^{\prime}=0 \mathrm{kPa}\right.$ and $\left.1000 \mathrm{kPa}\right)$, after isotropic loading $\left(p_{0}^{\prime}=900 \mathrm{kPa}\right.$ for the natural sediment and $1000 \mathrm{kPa}$ for the remoulded sediment), and after drained triaxial loading at $25 \%$ of axial strain. The number of tested specimens and their $e_{\text {poro }}$ void ratios, deduced from the MIP results, are summarised in Table 3, as are some of their mechanical characteristics.

In the initial state. The samples of remoulded sediment were extracted from the mould, where they were consolidated under an effective vertical stress $\sigma_{\mathrm{v}}^{\prime}=80 \mathrm{kPa}$. The samples of intact sediment were extracted from the core, the overburden effective stress being $\sigma_{\mathrm{v} 0}^{\prime}=36.5 \mathrm{kPa}$.

In comparison with the results obtained on the remoulded samples, the porosimetric curves (Fig. 9(a)) show a very high porosity of the natural sediment, which corroborates the behaviour observed at the macroscopic level. The poresize distribution of the natural sediment is complex, and the curve presents several peaks in the $15-40 \mu \mathrm{m}$ range which may correspond to inter- or trans-assemblage pores, according to the terminology of Collins \& McGown (1974). In both natural and remoulded specimens, one observes the presence of two peaks in the curves (Fig. 9(b)), with a first pore family which may be considered as an inter-aggregate type, with an average diameter of about $1 \mu \mathrm{m}$ in the natural sediment and about $1.25 \mu \mathrm{m}$ in the remoulded case; and a second pore family of the intra-aggregate type, with an identical average diameter of about $0.063 \mu \mathrm{m}$ for both materials.

Even if there is a large diversity in the natural sediment structure due to its high heterogeneity, a large number of images indicate that the porosity consists of an irregular network of pores crossing the material, as shown in Fig. 9(c). This observation seems to constitute a marked difference from the remoulded material (Fig. 9(d)), where the fabric appears as a packing of aggregated particles separated by pores (Hattab \& Favre, 2010).

After oedometric loading. The porosity change (Fig. 10(a)) under oedometric loading seems to be directly related to the closure of the inter-aggregate pores. This is clearly highlighted by the kinetics of the incremental curves from the initial state (Fig. 9(b)) to the oedometric loading state (Fig. $10(b))$.

(a) At $\sigma_{\mathrm{v}}^{\prime}=200 \mathrm{kPa}$, the average diameter of the interaggregate pores decreases significantly, from 1 to $0.4 \mu \mathrm{m}$ in the natural sediment and from 1.25 to $0.48 \mu \mathrm{m}$ in the remoulded one. The intra-aggregate porosity remains unchanged, with an average diameter of about $0.065 \mu \mathrm{m}$.

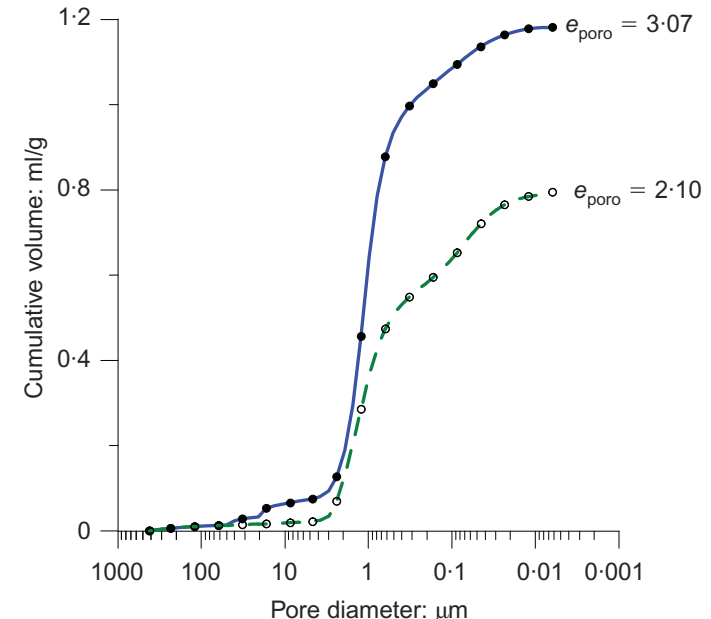

(a)

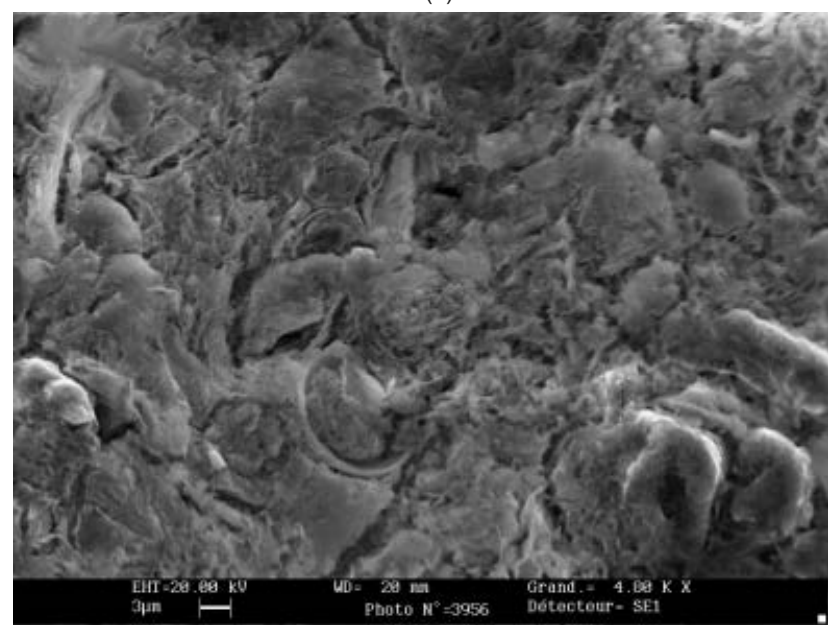

(c)

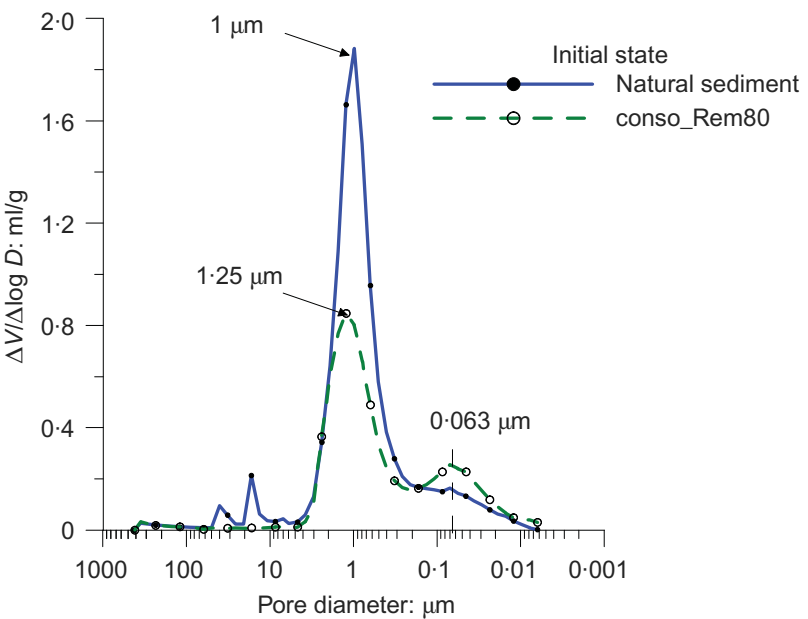

(b)

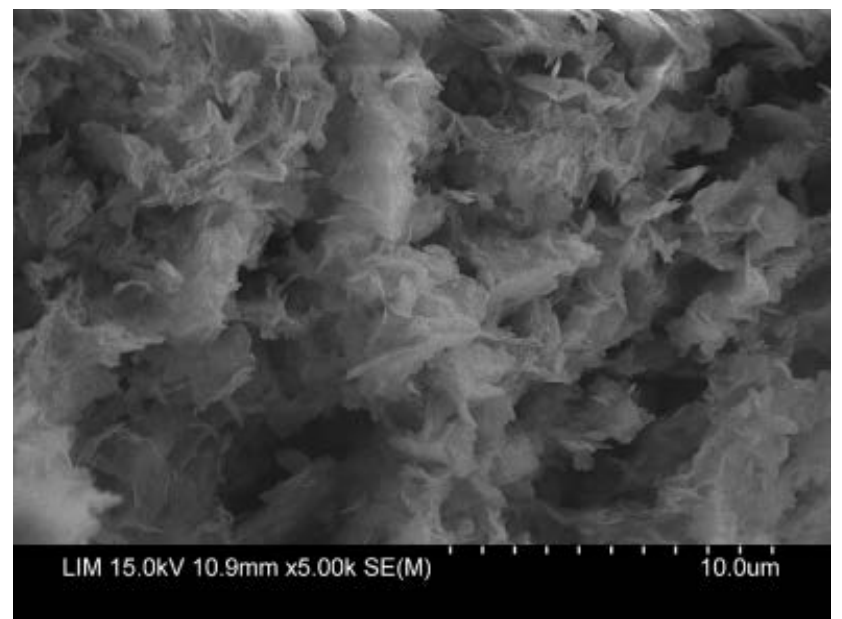

(d)

Fig. 9. Natural and remoulded microstructures of sediment in initial state: (a) MIP cumulative volume results; (b) MIP incremental volume results; (c) SEM photo of natural sediment; (d) SEM photo of remoulded sediment 


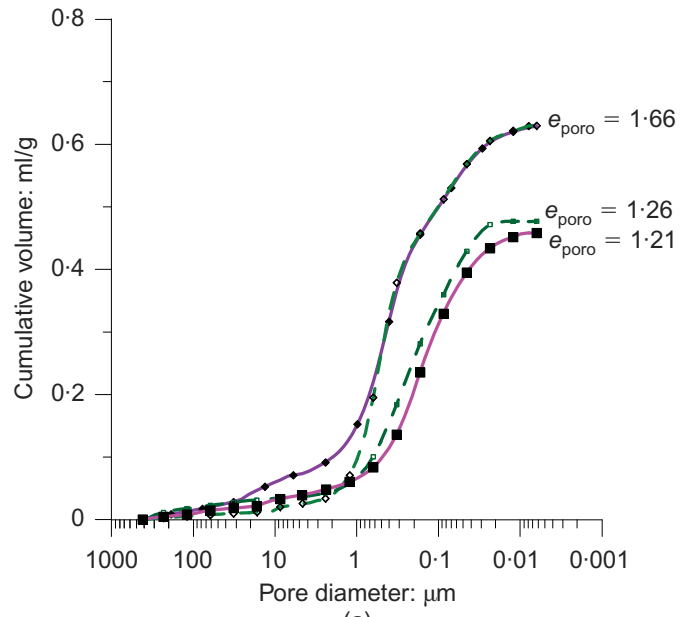

(a)

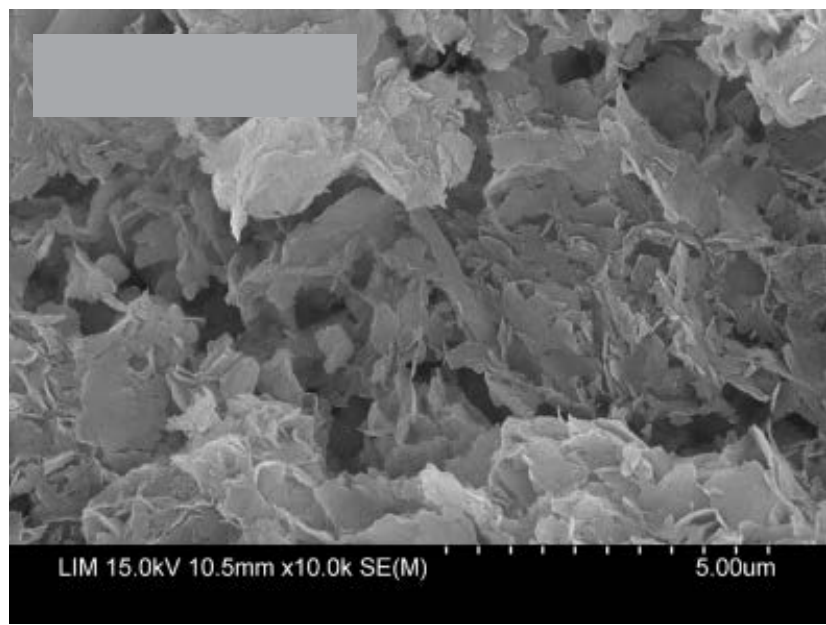

(c)

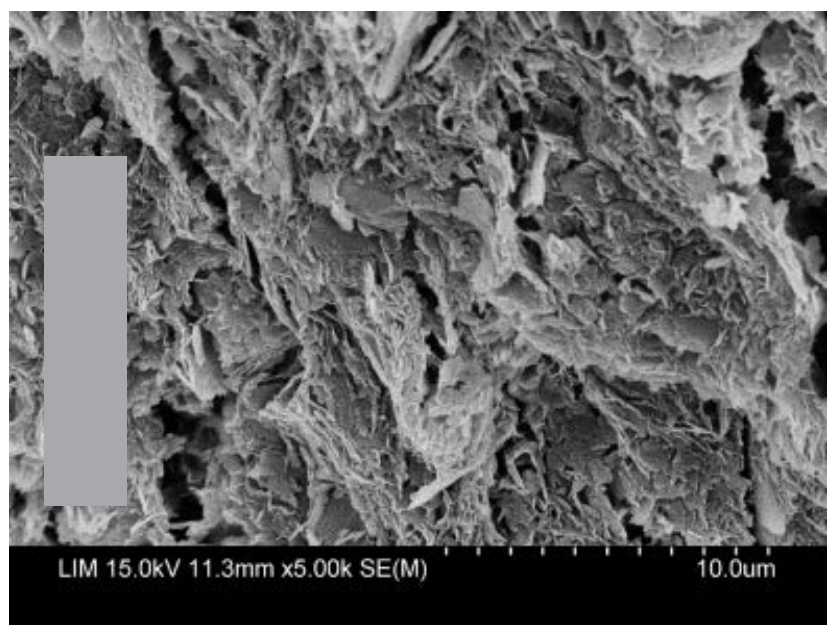

(e)

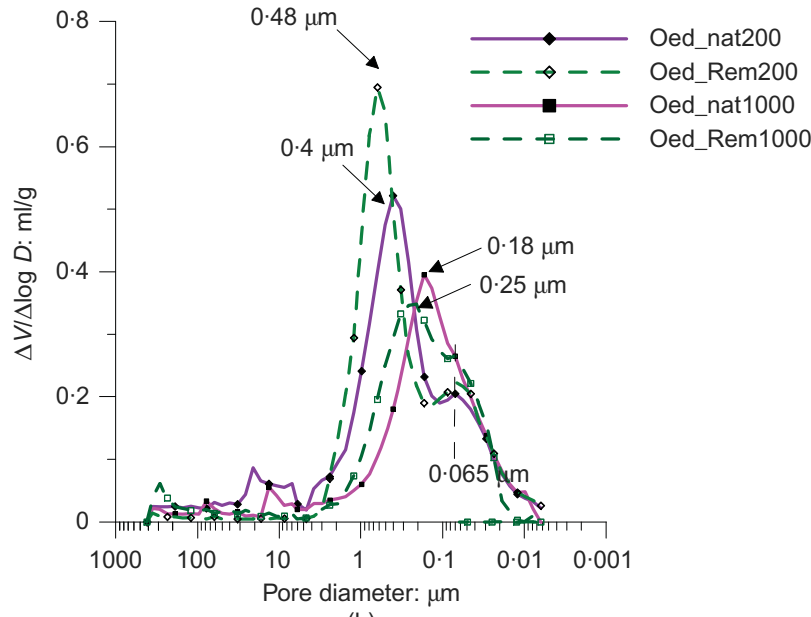

(b)

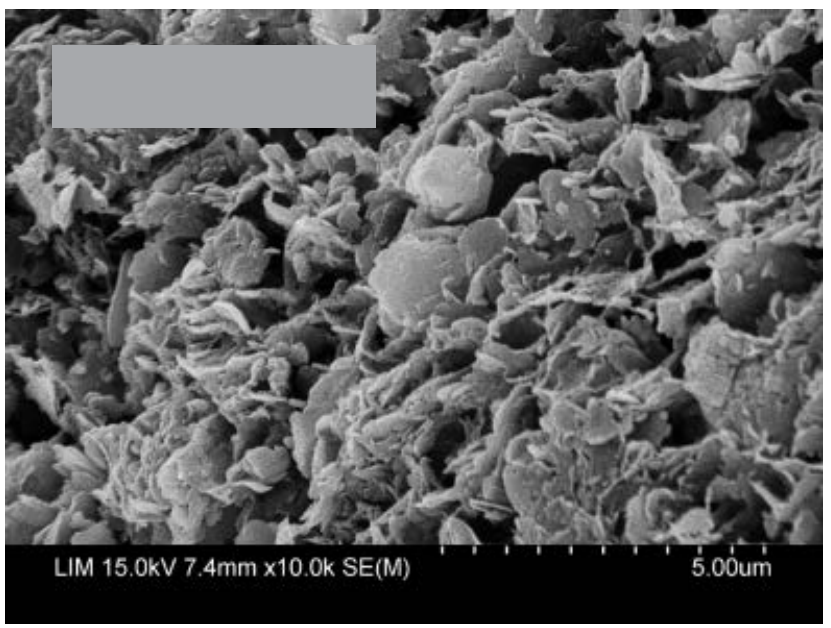

(d)

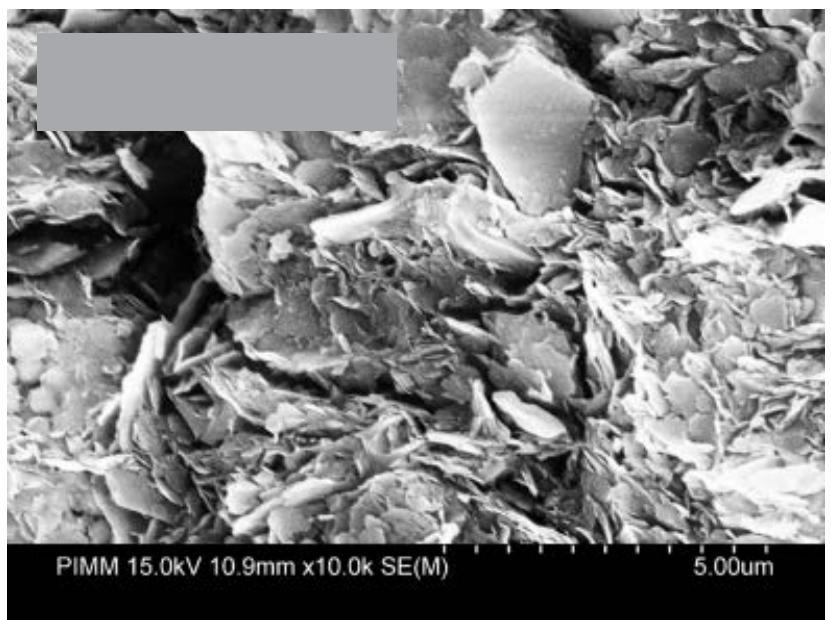

(f)

Fig. 10. Natural and remoulded microstructures of sediment after oedometric loading; (a) MIP cumulative volume results; (b) MIP incremental volume results; (c) SEM photo of natural sediment at $200 \mathrm{kPa}$ loading; (d) SEM photo of remoulded sediment at $200 \mathrm{kPa}$ loading; (e) SEM photo of natural sediment at $1000 \mathrm{kPa}$ loading; (f) SEM photo of remoulded sediment at $1000 \mathrm{kPa} l 0 a d i n g$

(b) At $\sigma_{\mathrm{v}}^{\prime}=1000 \mathrm{kPa}$, the average diameter of the interaggregate pores continues to decrease, with a value equal to $0.25 \mu \mathrm{m}$ in the remoulded sediment and $0 \cdot 18 \mu \mathrm{m}$ in the natural one. Similarly to the macroscopic behaviour, the cumulative curves of the natural and remoulded sediment converge towards each other, giving very close values of the void ratio $\left(e_{\text {poro }}\right)$.

SEM observations of remoulded clay at $\sigma_{\mathrm{v}}^{\prime}=200 \mathrm{kPa}$ and
$1000 \mathrm{kPa}$ (Figs 10(d) and 10(e)) reveal a structural organisation of the particles oriented towards the horizontal direction (following the illustration of Fig. 4). The same type of structure, however, is not so clearly perceptible in the SEM photos of intact sediment (Figs 10(c) and 10(f)).

After isotropic loading. Whether the sediment is intact or remoulded, the inter-granular pores are strongly reduced. The 
average diameter of the pores is about $0 \cdot 17 \mu \mathrm{m}$ in the intact sediment and about $0 \cdot 11 \mu \mathrm{m}$ in the remoulded one (Fig. 11(b)). The curves of cumulative intrusion volume are very close (Fig. 11(a)), but nonetheless indicate a higher porosity for the intact sediment, despite being loaded to a lower $p_{0}^{\prime}$. This confirms the macroscopic behaviour (Fig. (5(b)), which shows that the isotropic path corresponding to the natural sediment tends towards, but without ever reaching, the remoulded isotropic path (at $p^{\prime}=900 \mathrm{kPa}$ ). SEM images corroborate this analysis, revealing a difference of structure in the two materials. The main difference seems to be as follows. The microstructure of the natural sediment consists of aggregates with a random orientation of particles (Fig. $11(\mathrm{c})$ ). In the remoulded material, the individual aggregates observed in the initial state can no longer be distinguished; the particles remain mainly oriented towards the horizontal direction (Fig. 11(d)), which shows that the effect of the initial one-dimensional consolidation, before the isotropic loading, has not been completely erased. Thus a microstructural organisation similar to the one usually observed in laboratory-prepared remoulded clays is obtained, where particles can move freely and change orientation during loading (Hattab \& Fleureau, 2011).

After $\sigma_{3}=$ constant triaxial loading at $25 \%$ axial strain. The mechanical loading for the remoulded sediment (Fig. 12) is $\sigma_{3}^{\prime}=100 \mathrm{kPa}, 200 \mathrm{kPa}$ and $600 \mathrm{kPa}$, and for the natural sediment (Fig. 13) is $\sigma_{\mathrm{v}}^{\prime} \mathrm{Z}=40 \mathrm{kPa}, 200 \mathrm{kPa}$ and $600 \mathrm{kPa}$.

Porosimetric curves show a decrease in porosity with increase of the effective radial stress, the void ratio ranging from 2.15 to 0.87 within the remoulded sediment (Fig. 12(a)) and from $2 \cdot 72$ to $1 \cdot 15$ within the intact sediment (Fig. 13(a)). These results are in agreement with the volume change during consolidation and the contractant behaviour during the axial compression observed at the macroscopic level (Fig. 6). They are also in agreement with the fact that the triaxial paths in the $\log p^{\prime}-e$ plane for intact specimens tend towards the remoulded specimen paths at the end of the loading, but without reaching it, which corresponds to a larger void ratio in the intact specimens (Fig. 7). The kinetics of the incremental curves shows that the deformation mechanisms, such as in the previous loading cases, are linked to changes in the inter-aggregate pores. The average diameter of the pores varies from 1.8 to $0.083 \mu \mathrm{m}$ in the remoulded sediment (Fig. 12(b)), and from 1.2 to $0 \cdot 16 \mu \mathrm{m}$ in the intact sediment (Fig. 13(b)). The intra-aggregate pores are not affected, the average diameter remaining equal to about $0.06 \mu \mathrm{m}$. One can note, however, in the case of the $600 \mathrm{kPa}$ confining stress triaxial test (for the remoulded and intact case of the sediment; Figs 12 and 13) a decrease in the inter-aggregate poral space, owing to contraction of the material, which joins the volume occupied by the intraaggregate porosity.

SEM photos show successive bands of oriented particles,

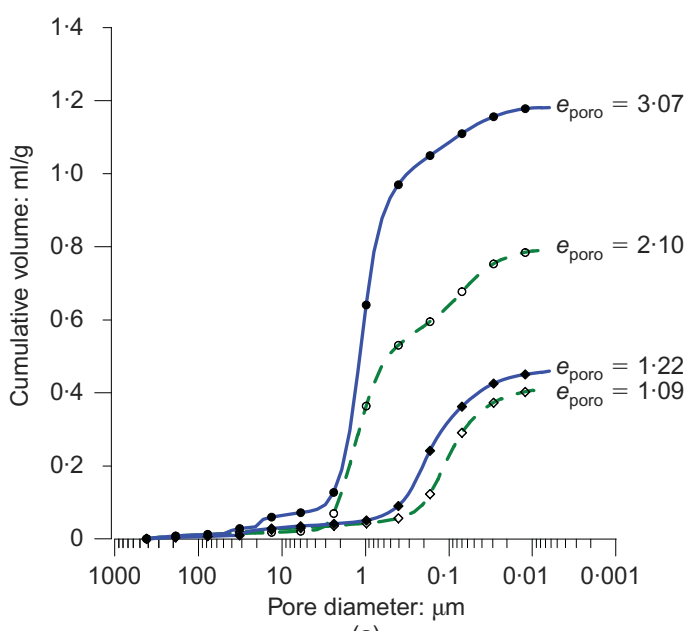

(a)

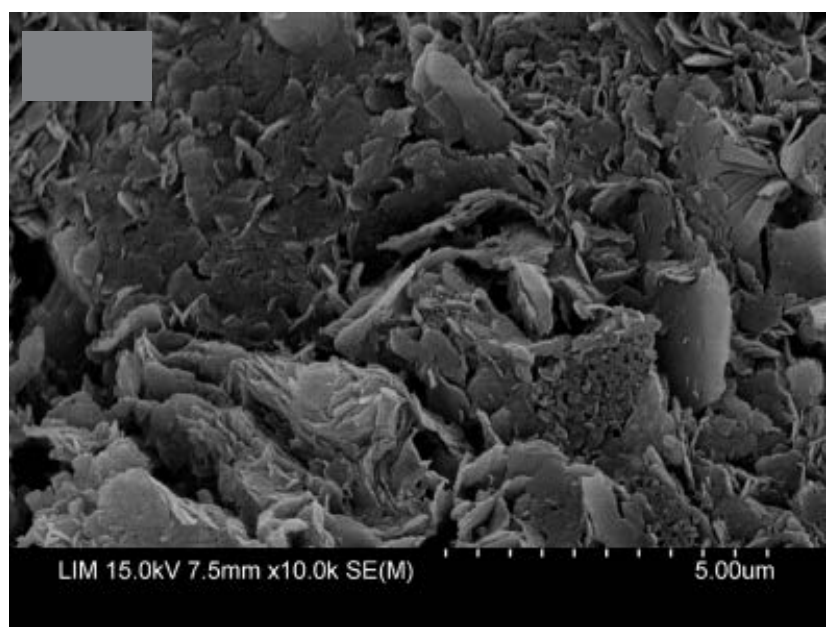

(c)

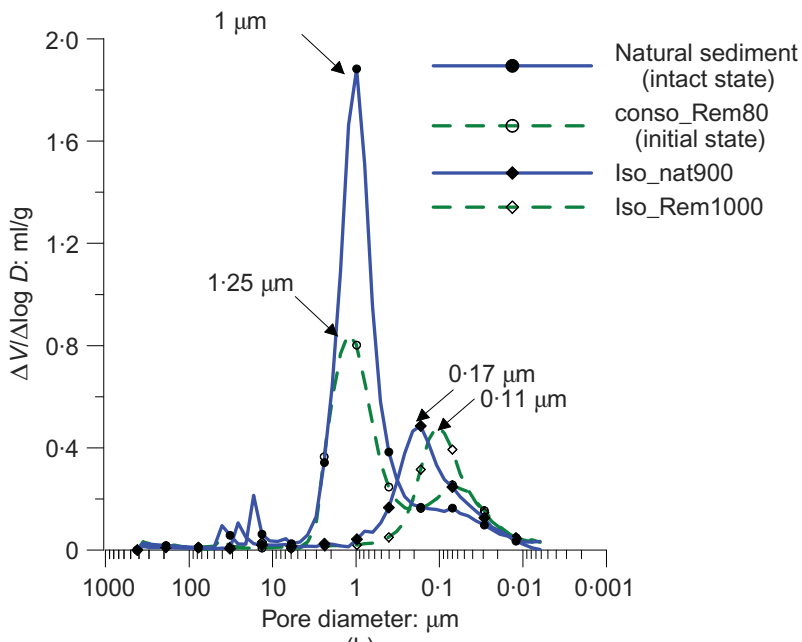

(b)

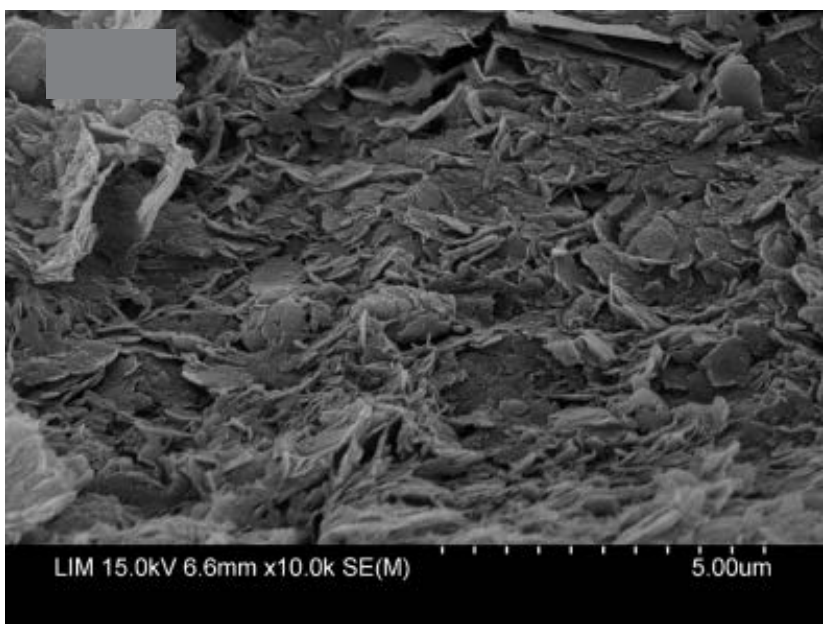

(d)

Fig. 11. Microstructure of sediment after isotropic loading: (a) MIP cumulative volume results; (b) MIP incremental volume results; (c) SEM photo of natural sediment at $900 \mathrm{kPa}$ loading; (d) SEM photo of remoulded sediment at $1000 \mathrm{kPa}$ loading 


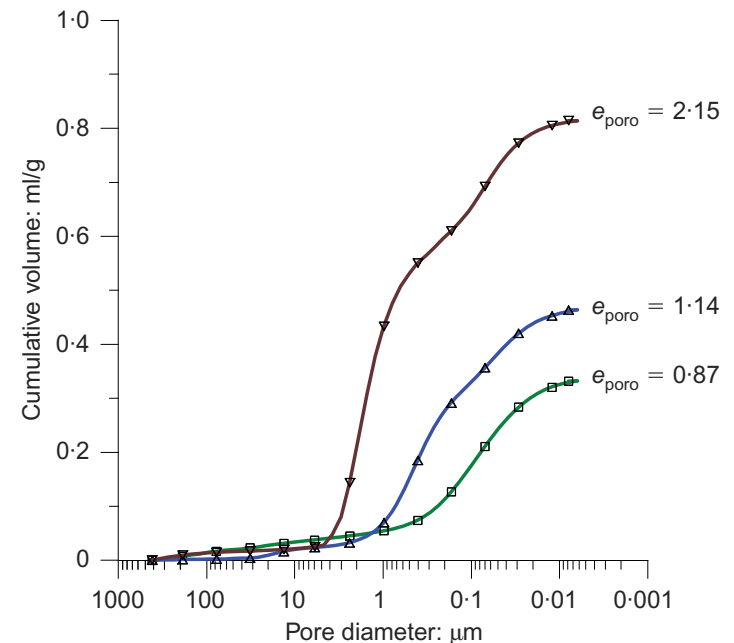

(a)

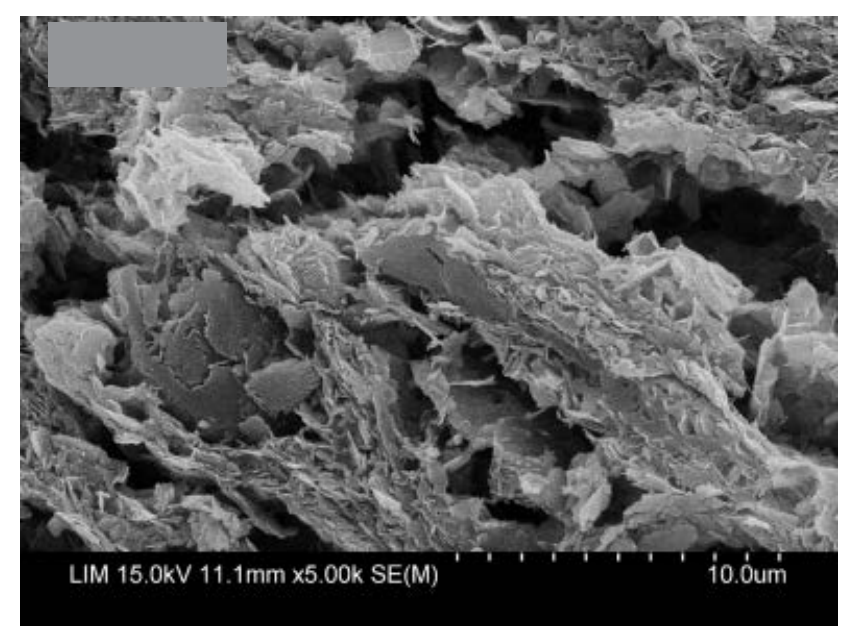

(c)

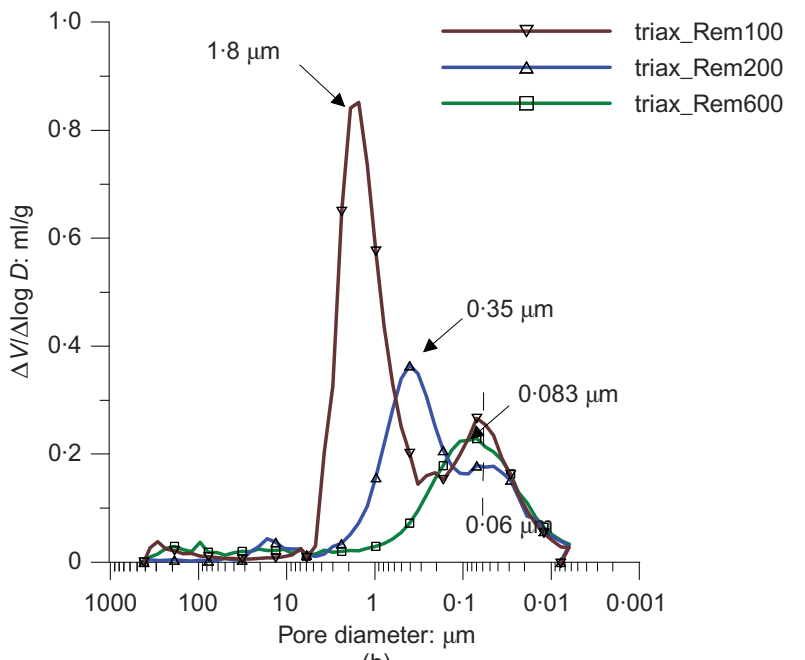

(b)

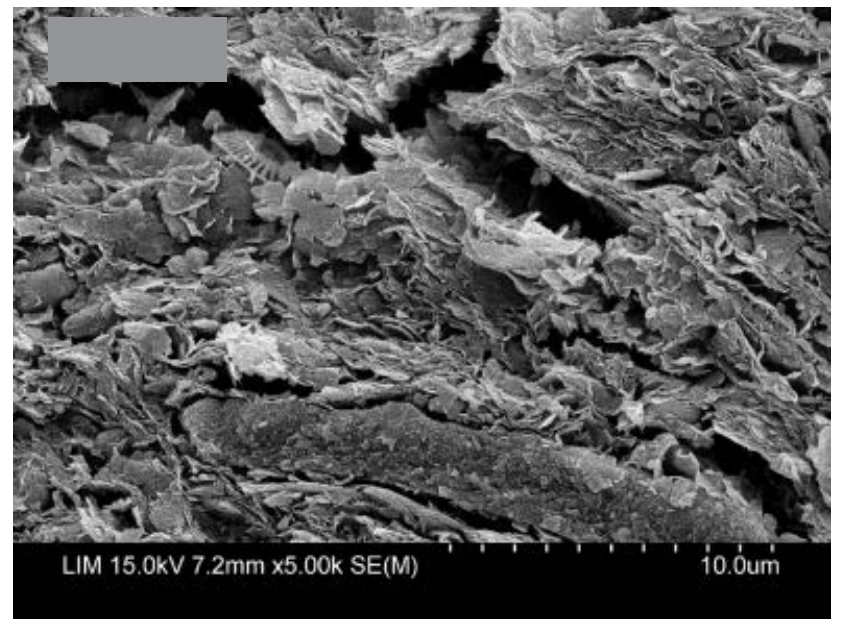

(d)

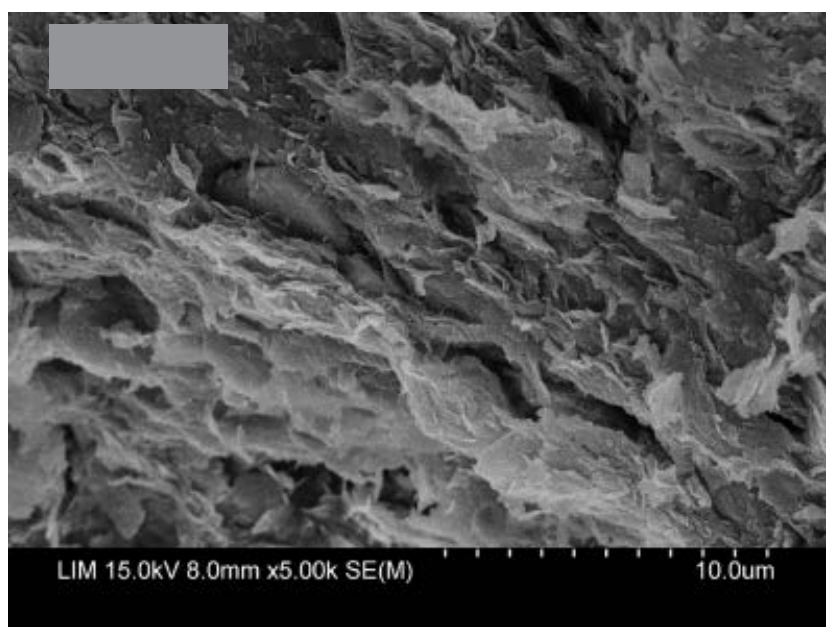

(e)

Fig. 12. Microstructure of remoulded sediment after triaxial loading: (a) MIP cumulative volume results; (b) MIP incremental volume results; (c) SEM photo at $100 \mathrm{kPa}$ loading; (d) SEM photo at $200 \mathrm{kPa}$ loading; (e) SEM photo at $600 \mathrm{kPa}$ loading

which are clearly visible in the remoulded material (Fig. 12). These bands are separated by cracks that appear more open when the consolidation stress is smaller. This could be caused by the necessary unloading at the end of the tests to recover the specimens used for the microscopic study. An oriented structure is much less visible in the natural sediment (Fig. 13); it is nevertheless apparent in some parts of the material, and seems to be more frequent as the material becomes closer to the remoulded one under higher stresses.

\section{Discussion}

One of the major conclusions that can be drawn from this microstructural analysis is that the mechanisms of volumetric deformation are due mainly to aggregates sliding. In all the studied loading cases, the inter-aggregate pore volume decreases, whereas the intra-aggregate pore volume remains fairly constant. This reduction of the inter-aggregate pores is directly linked to the amplitude of the applied stress tensor for the remoulded material, whereas it is necessary to 


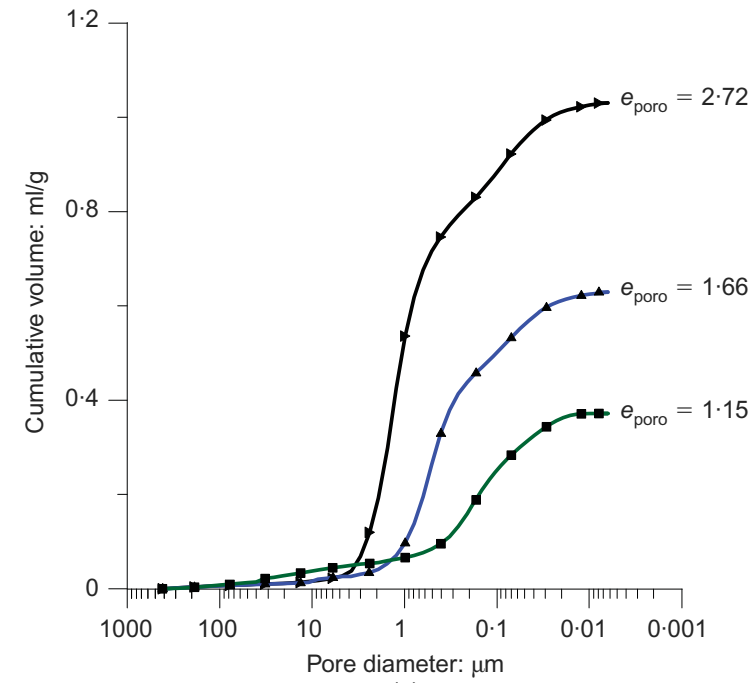

(a)

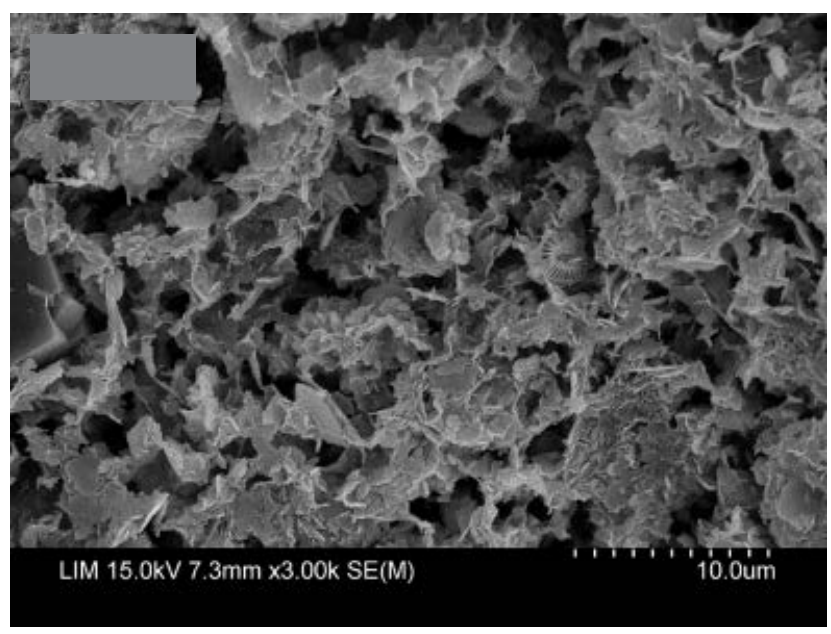

(c)

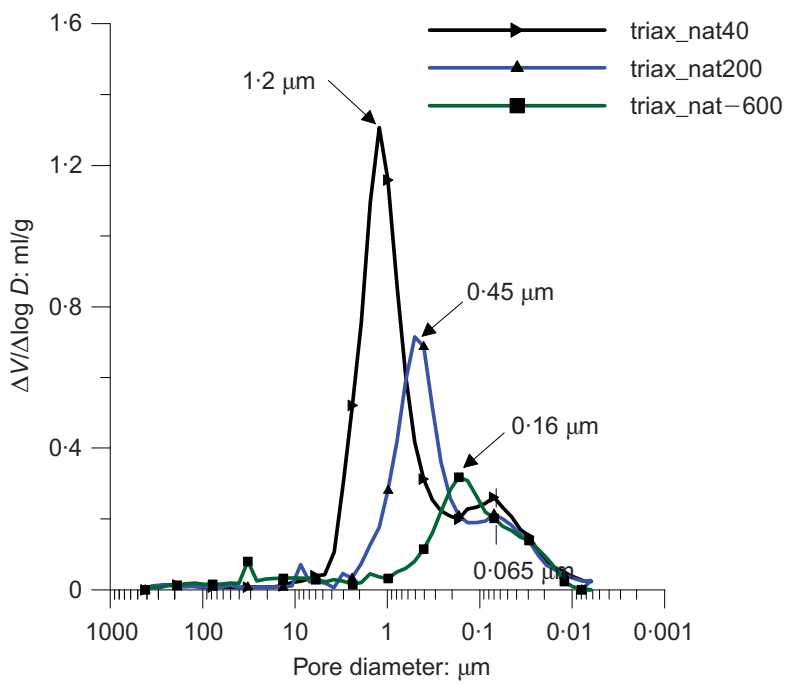

(b)

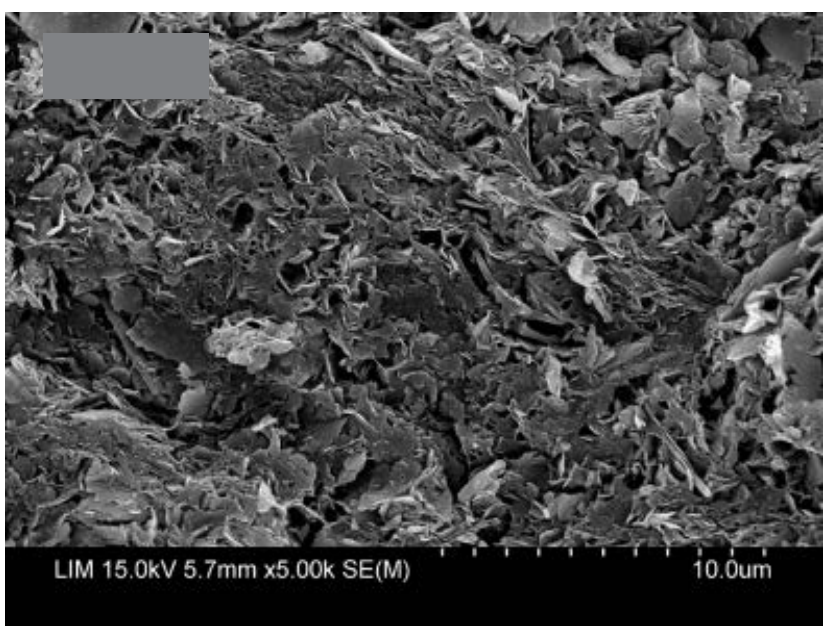

(d)

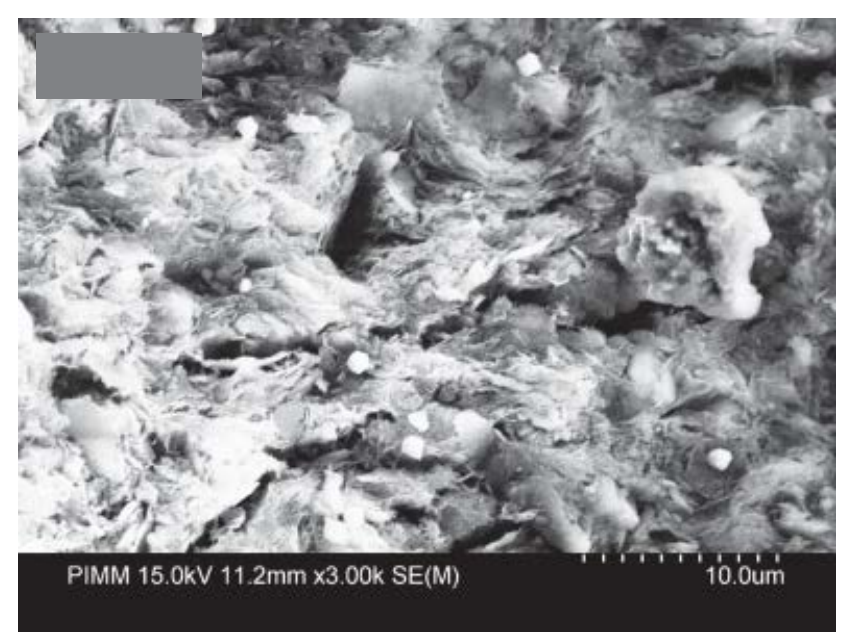

(e)

Fig. 13. Microstructure of natural sediment after triaxial loading: (a) MIP cumulative volume results; (b) MIP incremental volume results; (c) SEM photo at $40 \mathrm{kPa}$ loading; (d) SEM photo at $200 \mathrm{kPa}$ loading; (e) SEM photo at $600 \mathrm{kPa}$ loading

add the effect of cementation damage for the intact sediment. Under triaxial loading, SEM images suggest that preferential directions of particle groups are formed in the remoulded sediment, and parallel cracks develop between these groups. This result is in agreement with the microstructural evolution of normally consolidated remoulded clays (Hattab \& Fleureau, 2010, 2011). In the intact sedi- ment, preferential orientations concern only a few areas, which can be observed in the photographs of the specimens consolidated and then sheared under high stresses. The bonding between aggregates seems to delay greatly the reorientation mechanism. This reorientation becomes possible only when the progressive degradation of the bonds provides more freedom to the aggregates to slide against and 
rotate around each other. Therefore the microstructure of the intact specimens at the end of loading remains different from that characterising the remoulded specimens. Larger deformations would be needed to force the microstructure of the intact specimen to approach that of remoulded sediment.

\section{SUMMARY AND CONCLUSION}

This study dealt with the experimental behaviour of a deep-water marine sediment from a core $17 \mathrm{~m}$ long obtained at a depth of $700 \mathrm{~m}$ below sea level) in the GoG. By showing rare data on intact and remoulded deep-sea sediments whose extraction is quite difficult to carry out, this paper contributes to enrichment of knowledge on the behaviour of these complex materials. Different methods of analysis identified the sediment as corresponding to a smectitetype clay including numerous shell fragments, and some siliceous, organic and carbonated components. The mineralogical composition appears very complex, and is probably not uniform throughout the core.

An extensive mechanical study was undertaken on GoG samples along various loading paths, in order to describe clearly and quantify the material phenomenological behaviour. The particularly large distance in the $\log p^{\prime}-e$ plane between the ISL and CSL curves deduced from the remoulded material reveals the significant capability of the sediment to contract under triaxial loading, probably accentuated by the deformability and rupture of some organic elements within the material.

Along triaxial paths, two different domains of natural sediment behaviour could be identified: first, a small consolidation stress domain where isotropic loading had not yet damaged the sediment structure, which will eventually alter with the onset of triaxial loading until reaching failure; and second, a high consolidation stress domain where the material damage starts during the isotropic loading, and continues to develop along the triaxial path. It appears that the behaviour of the natural specimens converges towards that of the remoulded specimens, but without reaching it, even at the end of the loading.

The microstructural analysis in the initial state shows a complex porosity for the intact material and a bimodal porosity in the remoulded sediment. In both cases one can identify a first family corresponding to inter-aggregate pores, and a second family to intra-aggregate pores that have an identical average diameter in the two materials. During mechanical loading, volume changes obtained at the macroscopic specimen scale appear to be the result of a decrease in the inter-aggregate pore volume in both remoulded and intact specimens. Within the aggregate, where the pore size remains constant, the study reveals that a particle orientation mechanism is active in the remoulded material, whereas, for the intact material, the mechanical loading does not seem to alter the aggregate microstructure in a significant way.

Therefore this study shows that the microstructure of natural clayey sediment may be considered as an association of aggregates bonded by 'glue', which confirms the assumption of some researchers for sensitive clays. One of the assumptions that can be considered in the framework of micromechanical modelling (e.g. micromechanical modelling by Yin et al., 2011) is that deformation mechanisms, in the range of the studied stresses, occur mainly between aggregates, and can be associated with damage related to the degradation of the cementation, coupled with the decrease in the inter-aggregate pore sizes. The mechanism of particle reorientation - without volume change - is present within the remoulded material. In the natural sediment, it is probably necessary to increase the applied stresses in order to break the glue between the aggregates before it is possible to activate the particle reorientation mechanism as in the remoulded material.

\section{ACKNOWLEDGEMENTS}

The authors want to thank Fugro-France for providing the core of GoG material, and Mr J. Meunier, Mr J.-L. Nauroy, Mr A. Puech, Professor J.-L. Favre and Professor L. Toth for fruitful discussions. This work was initially conducted within the CLAROM 'Deep water sediments' project. Project partners were: IFP, IFREMER, Fugro-France, Saipem-SA, Stolt Offshore, Technip and Total.

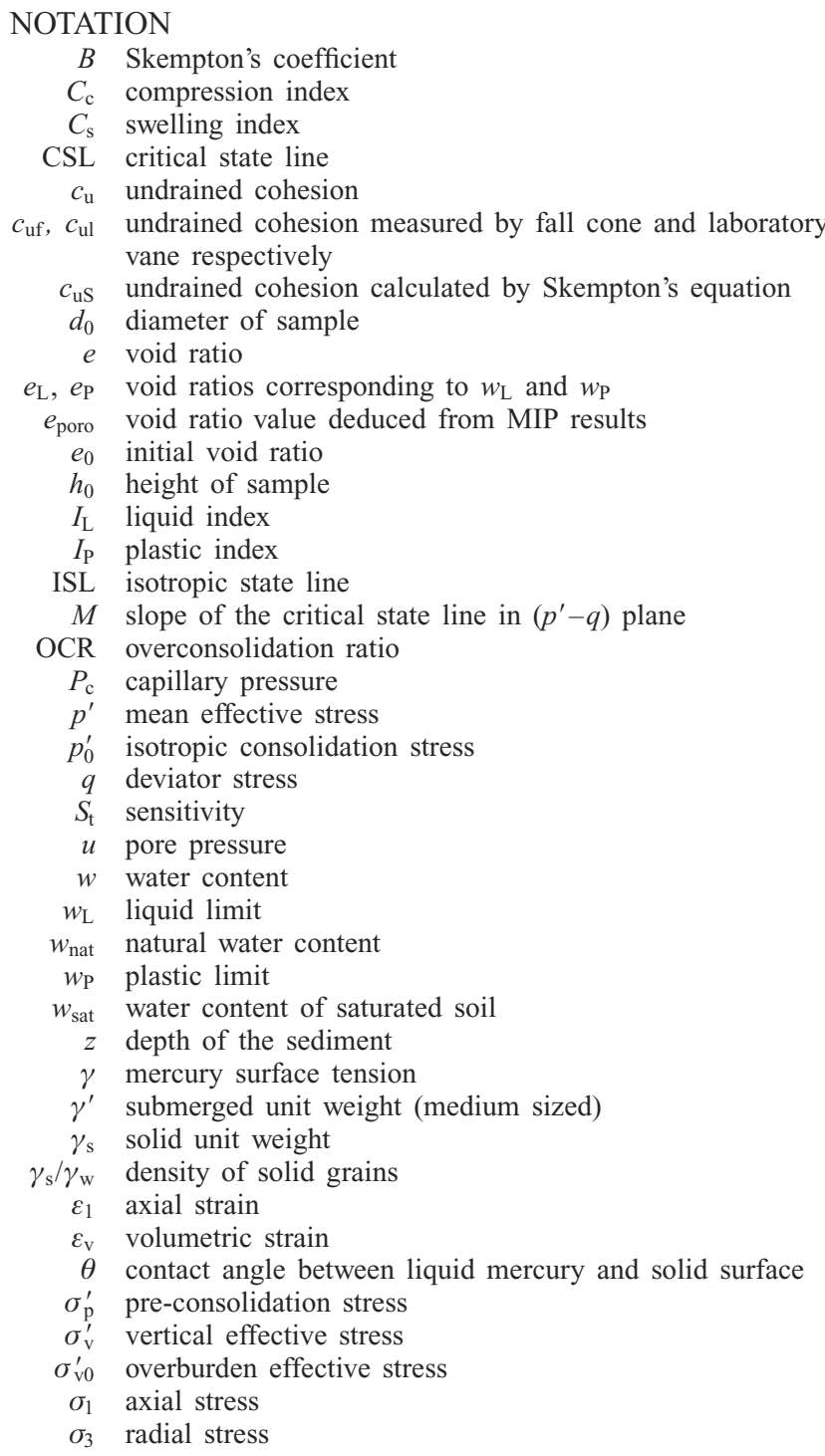

\section{REFERENCES}

Axelsson, K., Yu, Y. \& Westerberg, B. (1994). Behaviour and modelling of Swedish soft clay. Proc. 13th Int. Conf. Soil Mech. Found. Engng, New Delhi 1, 57-60.

Baudet, B. A. \& Ho, W. L. (2004). On the behaviour of deep-ocean sediments. Géotechnique 54, No. 9, 571-580, http://dx.doi.org/ 10.1680/geot.2004.54.9.571.

Been, K. \& Sills, G. C. (1981). Self-weight consolidation of soft soils: an experimental and theoretical study. Géotechnique 31, No. 4, 519-535, http://dx.doi.org/10.1680/geot.1981.31.4.519.

Biarez, J. \& Favre, J. L. (1977). Statistical estimation and extrapolation from observations. Proc. 9th Int. Conf. Soil Mech. Found. Engng, Tokyo 3, 505-509.

Biarez, J. \& Hicher, P. Y. (1994). Elementary mechanics of soil 
behaviour: Saturated remoulded soils. Rotterdam, the Netherlands: A. A. Balkema.

Biarez, J., Fayad, T., Taillez, S., Gomes Correia, A., Flavigny, E. \& Branque, D. (1998). Argiles et craies du tunnel sous la manche: grains sans et avec colle. Proc. 2nd Int. Conf. on Hard Soil and Soft Rocks, Napoli 1, 437-445.

Bishop, A. W. \& Wesley, L. P. (1975). A hydraulic triaxial apparatus for controlled stress path testing. Géotechnique 25, No. 4, 657-670, http://dx.doi.org/10.1680/geot.1975.25.4.657.

Blewett, J., McCarter, W. J., Chrisp, T. M. \& Starrs, G. (2001). Monitoring sedimentation of a clay slurry. Géotechnique 51, No. 8, 723-728, http://dx.doi.org/10.1680/geot.2001.51.8.723.

Burland, J. B. (1990). On the compressibility and shear strength of natural clays. Géotechnique 40, No. 3, 329-378, http:// dx.doi.org/10.1680/geot.1990.40.3.329.

Collins, K. \& McGown, A. (1974). The form and function of microfabric features in a variety of natural soils. Géotechnique 24, No. 2, 223-254, http://dx.doi.org/10.1680/geot.1974.24.2.223.

Cotecchia, F. \& Chandler, R. J. (1997). The influence of structure on the pre-failure behaviour of a natural clay. Géotechnique 47, No. 3, 523-544, http://dx.doi.org/10.1680/geot.1997.47.3.523.

Cotecchia, F. \& Chandler, R. J. (2000). A general framework for the mechanical behaviour of clay. Géotechnique 50, No. 4, 431447, http://dx.doi.org/10.1680/geot.2000.50.4.431.

De Gennaro, V., Puech, A. \& Delage, P. (2005). On the compressibility of deep water sediments of the Gulf of Guinea. Proc. Int Symp. on Frontiers in Offshore Geotechnics (ISFOG 2005), Perth, 1063-1069.

Delage, P. (2010). A microstructure approach to the sensitivity and compressibility of some Eastern sensitive clays. Géotechnique $\mathbf{6 0}$, No. 5, 353-368, http://dx.doi.org/10.1680/geot.2010.60.5.353.

Delage, P. \& Lefebvre, G. (1984). Study of the structure of a sensitive Champlain clay and of its evolution during consolidation. Can. Geotech. J. 21, No. 1, 21-35.

Delage, P. \& Pellerin, M. (1984). Influence de la lyophilisation sur la structure d'une argile sensible du Quebec. Clay Miner. 19, No. 2, 151-160.

Favre, J.-L. \& Hattab, M. (2008). Analysis of 'Biarez-Favre' and 'Burland' models of the compressibility of remoulded clays. $C$. R. Acad. Sci. Geosci. 340, No. 1, 20-27.

Frost, J. D. \& Yang, C. (2003). Effect of end platens on microstructure evolution in dilatant specimens. Soils Found. 43, No. 4, $1-11$.

Guillot, X., Bergaya, F., Fleureau, J.-M. \& Al-Mukhtar, M. (2001). Influence of stresses and suction on volume change behaviour and microscopic properties of a Ca-smectite. Proceedings of the international symposium on suction, swelling, permeability and structure of clays, Shizuoka, pp. 69-77.

Hattab, M. \& Favre, J.-L. (2010). Analysis of the experimental compressibility of deep water marine sediments from the Gulf of Guinea. Mar. Pet. Geol. 27, 486-499.

Hattab, M. \& Fleureau, J.-M. (2010). Experimental study of kaolin particle orientation mechanism. Géotechnique 60, No. 5, 323-331, http://dx.doi.org/10.1680/geot.2010.60.5.323.

Hattab, M. \& Fleureau, J.-M. (2011). Experimental analysis of kaolinite particle orientation during triaxial path. Int. J. Numer. Anal. Methods Geomech. 35, No. 5, 947-968.

Hattab, M. \& Hicher, P. Y. (2004). Dilating behaviour of overconsolidated clay. Soils Found. 44, No. 4, 27-40.
Hicher, P.-Y. (1985). Comportement mécanique des argiles saturées sur divers chemins de sollicitations monotones et cycliques, application à une modélisation élastoplastique et viscoplastique. $\mathrm{PhD}$ thesis, Université Pierre et Marie Curie, Paris, France (in French).

Hicher, P.-Y., Wahyudi, H. \& Tessier, D. (2000). Microstructural analysis of inherent and induced anisotropy in clay. Mech. Cohes.-Frict. Mater. 5, No. 5, 341-371.

Hong, Z. S., Yin, J. \& Cui, Y. J. (2010). Compression behaviour of reconstituted soils at high initial water contents. Géotechnique 60, No. 9, 691-700, http://dx.doi.org/10.1680/geot.9.P.059.

Hong, Z. S., Zeng, L. L., Cui, Y. J., Cai, Y. Q. \& Cheng, L. (2012). Compression behaviour of natural and reconstituted clays. Géotechnique 62, No. 4, 291-301, http://dx.doi.org/10.1680/geot. 10.P.046.

Koumoto, T. \& Houlsby, G. T. (2001). Theory and practice of the fall cone test. Géotechnique 51, No. 8, 701-712, http:// dx.doi.org/10.1680/geot.2001.51.8.701.

Lade, P. V. \& Tsai, J. (1985). Effects of localization in triaxial tests on clays. Proc. 11th Int. Conf. Soil Mech. Found. Engng, San Francisco, 549-552.

Leroueil, S., Tavenas, F., Brucy, F., La Rochelle, P. \& Roy, M. (1979). Behaviour of destructured natural clays. J. Geotech. Engng Div. ASCE 105, No. GT6, 759-778.

Lunne, T., Berre, T. \& Strandvik, S. (1998). Sample disturbance effects in deep water soil investigations. Proceedings of the international conference on offshore site investigation and foundation behaviour, London, pp. 199-219.

Martin, R. T. \& Ladd, C. C. (1975). Fabric of consolidated kaolinite. Clays Clay Miner. 23, No. 1, 17-25.

Mitchell, J. K. (1976). Fundamentals of soil behavior. New York, NY, USA: Wiley.

Morgenstern, N. R. \& Tchalenko, J. S. (1967). Microscopic structures in kaolin subjected to direct shear. Géotechnique 17, No. 4, 309-328, http://dx.doi.org/10.1680/geot.1967.17.4.309.

Pane, V. \& Schiffman, R. L. (1985). A note on sedimentation and consolidation. Géotechnique 35, No. 1, 69-72, http://dx.doi.org/ 10.1680/geot.1985.35.1.69.

Puech, A., Colliat, J.-L., Nauroy, J.-F. \& Meunier, J. (2005). Some geotechnical specificities of Gulf of Guinea deepwater sediments. Proc. Int. Symp. on Frontiers in Offshore Geotechnics (ISFOG 2005), Perth, 1047-1053.

Pusch, R. (1970). Microstructural changes in soft quick clay at failure. Can. Geotech. J. 7, No. 1, 1-7.

Schofield, A. N. \& Wroth, C. P. (1968). Critical state soil mechanics. New York, NY, USA: McGraw-Hill.

Skempton, A. W. (1954). The pore-pressure coefficients A and B. Géotechnique 4, No. 4, 143-147, http://dx.doi.org/10.1680/ geot.1954.4.4.143.

Skempton, A. W. \& Northey, R. D. (1952). The sensitivity of clays. Géotechnique 3, No. 1, 30-53, http://dx.doi.org/10.1680/geot. 1952.3.1.30.

Thomas, F., Rebours, B., Nauroy, J.-F. \& Meunier, J. (2005). Mineralogical characteristics of Gulf of Guinea deep water sediments. Proc. Int. Symp. on Frontiers in Offshore Geotechnics (ISFOG 2005), Perth, 19-21.

Yin, Z. Y., Hattab, M. \& Hicher, P.-Y. (2011). Multiscale modeling of a sensitive marine clay. Int. J. Numer. Anal. Methods Geomech. 35, No. 15, 1682-1702. 